Portland State University

PDXScholar

Fall 12-8-2015

\title{
Post-Revolutionary Mexican Education in Durango and Jalisco: Regional Differences, Cultures of Violence, Teaching, and Folk Catholicism
}

Lindsey Ellison Collins

Portland State University

Follow this and additional works at: https://pdxscholar.library.pdx.edu/open_access_etds

Part of the Latin American History Commons

Let us know how access to this document benefits you.

\section{Recommended Citation}

Collins, Lindsey Ellison, "Post-Revolutionary Mexican Education in Durango and Jalisco: Regional Differences, Cultures of Violence, Teaching, and Folk Catholicism" (2015). Dissertations and Theses. Paper 2722.

https://doi.org/10.15760/etd. 2718

This Thesis is brought to you for free and open access. It has been accepted for inclusion in Dissertations and Theses by an authorized administrator of PDXScholar. Please contact us if we can make this document more accessible: pdxscholar@pdx.edu. 
Post - Revolutionary Mexican Education in Durango and Jalisco:

Regional Differences, Cultures of Violence, Teaching, and Folk Catholicism

by

Lindsey Ellison Collins

A thesis submitted in partial fulfillment of the requirements for the degree of

Master of Arts
in
History

Thesis Committee:

Friedrich E. Schuler, Chair

Tim Garrison

Joseph Bohling

Roberto de Anda

Portland State University

2015 


\begin{abstract}
This thesis explored a regional comparison of education in post revolutionary Mexico. It examined the relationship between violence, education, religion, and politics in the states of Durango and Jalisco. Research methods included primary sources and microfilms from the National Archives State Department records related to education from the internal affairs of Mexico from 1930 -1939 from collection file M1370. It also utilized G -2 United States Military Intelligence reports as well as records from the British National Archives dealing with church and state relations in Mexico from 1920-1939.

Anti - clericalism in the 1920's led to violent backlash in rural regions of Durango and Jalisco called the Cristero rebellion. A second phase of the Cristero rebellion began in the 1930s, which was aimed at ending state - led revolutionary secular education and preserving the folk Catholic education system. There existed a unique ritualized culture of violence for both states. Violence against state - led revolutionary secular educators was prevalent at the primary and secondary education levels in Durango and Jalisco. Priests served as both religious leaders and rebel activists.

At the higher education level there existed a split of the University of Guadalajara but no violence against educators. This comparison between two regions within the broader context of the country and its experiences allowed for analysis in regards to education, rebellion, religion, and politics.
\end{abstract}


For my son, Fox. 


\section{Acknowledgements}

I would first and foremost like to thank my thesis advisor professor Friedrich E. Schuler for all of his help throughout this process. He remained available and willing to assist me every step of the way. For this I will be forever in his debt. Not only did I become a historian, I was given the tools to succeed as a historian in the future.

Next I would like to thank professor Tim Garrison, professor Roberto de Anda, and professor Joseph Bohling for being a part of my thesis committee.

I would also like to thank professor of modern Latin American history Grover Antonio Espinoza Ruiz from Virginia Commonwealth University who sparked my interest in Latin American History and especially the subject of the history of education in Peru and Mexico. I would also like to thank the following educators from the study abroad program at VCU professor of painting Javier Tapia, Professor of photography Scott Dupre Mills, and Dr. Michael Panbehchi who both encouraged me to continue my education. Professor Ryan K. Smith, thank you for pushing me to continue my education.

Thank you to my family, my mom, dad, and sister. Finally, I would like to thank my husband Jay and my son, Fox. Thank you for supporting me. To my son Fox, thank you for allowing me to be your mother. Everyday I love you more. 


\section{Table of Contents}

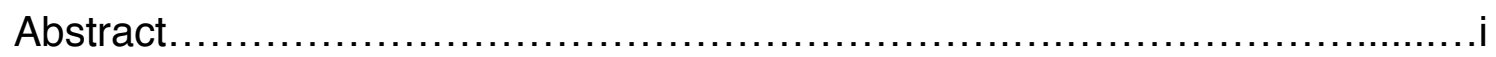

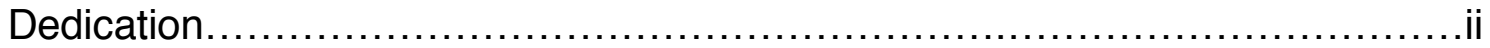

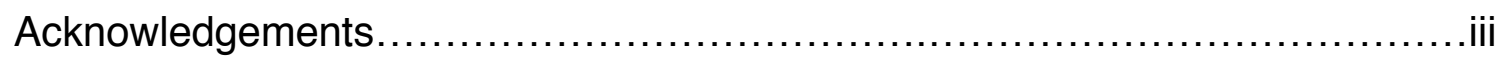

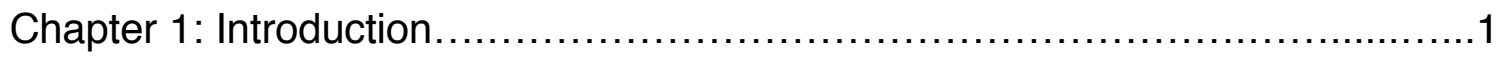

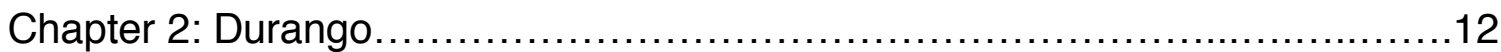

A. Durango's Regional Culture of Violence: Rebel Side......................................................................

B. Government Side of the Culture of Violence in

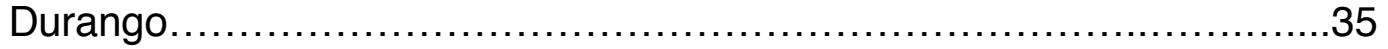

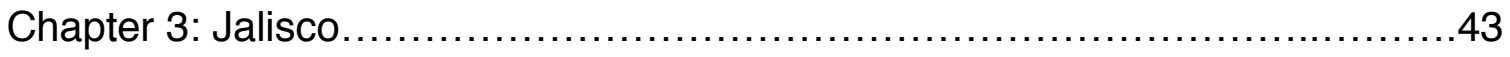

C. Jalisco's Culture of Violence: Rebel

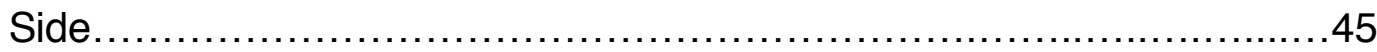

D. Culture of Violence: Government

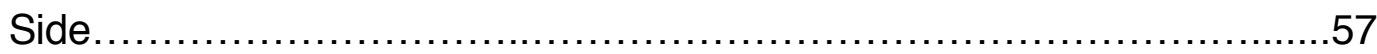

E. Higher Education: The

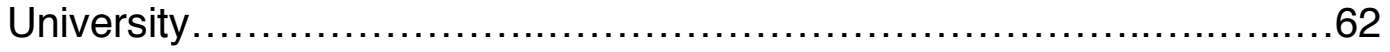

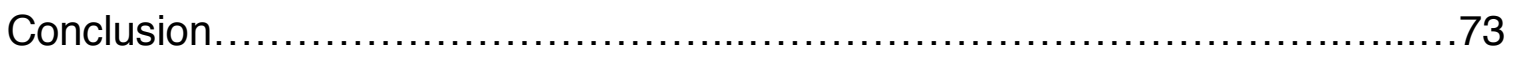

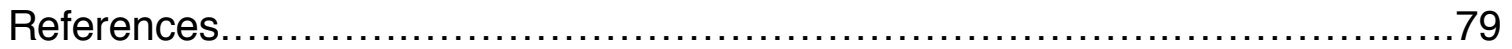




\section{Chapter 1: Introduction}

On September 26, 2014 a group of 43 radical students disappeared in the southern Mexican state of Guerrero. ${ }^{1}$ Eventually investigations showed that a local mayor and his wife, because of politics, had chosen to have the students killed. $^{2}$

This story stands in the tradition of similar events in Mexico going back to the 1920s however, the 1930s will be the focus of this thesis.

The geographical focus will be the states of Durango and Jalisco. The example of these two states and their history will be explored in depth in the interrelationship between education, politics, and social behavior, with a particular focus on the two decades of the 1920s and 1930s. They have not been studied in such a way and over this time span.

A person not familiar with Mexican history might think in Durango and Jalisco education might have been strictly a pedagogical and administrative matter. However newly discovered sources from the era of $1929-1941$ suggest it resembled more a wide stage where rebellions, regional banditry, and religion interacted. These interactions created cultures of violence whose components will be examined in detail.

This thesis became possible because of new sources I found in the U.S. National Archives located in College Park, Maryland. The U.S. Department of

\footnotetext{
1 "Is the Case of the 43 Missing Students in Mexico Closed?", last modified January 28, 2015, http://www.cnn.com/2015/01/28/americas/mexico-missing-students/.

2 Ibid.
} 
State records related to education from internal affairs of Mexico from 1930-1939 (collection file M1370) formed the basis of this thesis. Second, U.S. military intelligence reports (G-2) offered an additional window into general contemporary culture of Durango and Jalisco.

Next, I wanted a second set of cultural eyes on this topic. Thus, I consulted records from the British National Archives Kew Garden titled "Mexican religious activities of the 1930s." They have not been used before in this context.

The absence of Mexican sources is due to a lack of private funds or scholarships to undertake such research in Durango and Jalisco. Moreover traveling to Durango has become dangerous because drug cartels dominate rural areas and engage in kidnapping. Rural Jalisco is in similar state of social deterioration. Future researchers need to look into local sources and have to adjust my findings.

I recognize that the look through the historical window about to be presented is skewed due to the preponderance of Anglo Saxon sources. Thus this is only a preliminary finding and final understanding about Jalisco and Durango comes about only after we have added Mexican sources.

This work builds on the work that has been published between 1980 and 1990 by the following scholars: Jean Meyer, Mary Kay Vaughan, Stephen E. Lewis, Adrian Bantjes, and Marjorie Becker. All five texts focused on education in Mexico. Each offered a look at a particular state. Yet none of them made education and its culture in Durango or Jalisco their center of examination. 
Mary Kay Vaughan contributed three books to the topic of education in Mexico. All her texts are general analyses of the history of education in Mexico, complete with statistical data about select states.

In The State, Education, and Social Class in Mexico, 1880-1928, she focused on state education policy on public primary schools. ${ }^{3}$ The text shined a light on how modernizing, state sponsored schooling evolved when it functioned. Vaughan highlighted the limits of Porfirian $^{4}$ schooling and the challenge of teaching students who speak indigenous languages and cannot read or write in Spanish.

She had not addressed questions dealing with education at the university level. I build on this work by contributing a micro - view of the states of Durango and Jalisco, and expand her frame of reference by including the story of the university in Jalisco. Here higher education rested within a larger setting of primary and secondary education and added further complexity to the regional story.

In her second book, Cultural Politics in Revolution: Teachers, Peasants, and Schools in Mexico, 1930 - 1940, she examined four regions and their differences during the $1930 \mathrm{~s} .{ }^{5}$ Two states she investigated were Puebla in central Mexico and Sonora in the Northeastern area of Mexico. Politics of schooling

\footnotetext{
${ }^{3}$ Mary Kay Vaughan, The State, Education, and Social Class in Mexico: 1880-1928, (DeKalb: Northern Illinois University Press, 1982).

${ }^{4}$ Porfiriato: Mexican dictatorship 1876 - 1910 led by Porfirio Diaz.

${ }^{5}$ Mary Kay Vaughan, Cultural Politics in Revolution: Teachers, Peasants, and Schools In Mexico, 1930-1940, (Tucson, University of Arizona Press: 1997).
} 
were examined in the rural communities of Tecamachalco, and Zacapoaxtla, both of them in Puebla. Then she looked into events taking place along the right bank of the Yaqui River and the Pueblo Yaqui society. Her goal was to explain events in the 1930 s by linking them to their origin during the earlier phase of the Mexican Revolution from 1910-1920.

Vaughan's vantage point was forward looking, describing the introduction of compulsory state education as part of economic modernization, agrarian reform, and a changing export oriented economy. To this she added the introduction of new technologies and social movements such as female led antialcohol and hygiene campaigns. All of them were extremely offensive to the social reality of indigenous communities.

The book, The Eagle and The Virgin: Nation and Cultural Revolution in Mexico, 1920-1940, was written by Vaughan and Lewis and focused on the nation -building project in Mexico following the Mexican Revolution. ${ }^{6}$ It highlighted the visual arts, Mexican muralists, and their role in this project in regards to education in Mexico. The text described how this project played out in individual Mexican states and how it differed there in terms of local religion and cultural -revolution in Mexico.

These historians main research question was, "How did these distinct symbols and practices, memories and utopian projections coexist and intersect in these years of reform, protest, and state construction and how they

\footnotetext{
${ }^{6}$ Mary Kay Vaughan and Stephen E. Lewis, The Eagle and The Virgin: Nation and Cultural Revolution in Mexico, 1920-1940, (Durham, Duke University Press: 2006).
} 
forged one of the strongest cultural nations in the Western hemisphere?"7 They concluded that, "They are organized in four parts. The first part addresses the aesthetics of nation - building in popular arts, music, painting, and architecture. The second looked at utopian state projects of behavioral transformation in health, anticlericalism, and education and the ways Mexicans received these. The third examined the role of mass communication (roads, cinema, and radio) in nation formation. The fourth probed national identity formation as it took shape in distinct regions of the country among industrial workers, and middle - class women."

Although this book did not focus on education, it is vital to the history of education in Mexico because it showed that even though the national Revolution happened there were still regions where Porfirian ideals were being upheld.

In contrast, my work focuses on two regions that rejected national advance and rejected a national educational revolution and fought it to a draw. Again, while Vaughan's focus was nation building and the imposition of a new educational culture onto the rest of the nation. My work is concerned with the rejection of national state policy. It asks how this rejection expressed itself in actions and symbols. It adds a forgotten sides part of the same process.

Vaughan argued that each of the places she looked at had its own separate history and background before the revolution. Therefore, national education reform was received differently in each state. My research adds to

\footnotetext{
7 Ibid., 2.

${ }^{8}$ Ibid.
} 
Vaughan's work by providing a detailed look at Durango and Jalisco.

Unlike Vaughan, I go beyond political history and state formation theory and investigate how on the ground rebellion against modern education, and religion was experienced.

Stephen E. Lewis, examined in The Ambivalent Revolution: Forging State and Nation in Chiapas, 1910-1945, education through the lens of the rural schoolhouse in the eastern state of Chiapas between 1934 and $1940 .{ }^{9}$ He looked at the topic of education and how it was part of the process to "Mexicanize" relatively culturally autonomous states. His unique contribution was the illumination of the special role played by festivals and sports as part of this nationalist curriculum. He proved that in the highlands near the Guatemalan border this meant wrestling away control over the ancient native calendar and replacing syncretic Mayan-Spanish colonial cults of the saints with a new cult of the state. Mexico City teachers in Chiapas prepared civic, patriotic, and/ or sporting festivals at a, sometimes, frantic rate of roughly one event per week. ${ }^{10}$ For my work his findings related too much to a Mayan mindset and indigenous religion. The identity of the people in the states of Jalisco and Durango was one of ethnic blending exclusively based on a mestizo past. ${ }^{11}$

Jean Meyer's The Cristero Rebellion gave a detailed look at the rebellion

\footnotetext{
${ }^{9}$ Stephen E. Lewis, Ambivalent Revolution: Forging State and Nation in Chiapas, 1910-1945, (Albuquerque, University of New Mexico Press: 2005), xii.

${ }^{10}$ Ibid. , xvii.

${ }^{11}$ Mary Kay Vaughan, The State, Education, and Social Class in Mexico, 1880-1928, (Dekalb, Northern Illinois University, 1982).
} 
for the areas of Zacatecas, Los Altos de Jalisco, and Durango. His work remains the most important Spanish - speaking source of the Cristero Rebellion. ${ }^{12} \mathrm{He}$ introduced new characters of the rebellion, such as Lauro Rocha, to the plot as well as photographs of the events.

Still, Jean Meyer wrote from a highly partisan perspective and celebrated in the book his pro-Catholic leanings. His main concern remained limited to doing justice to the cause of the repressed Catholics and their way of life, not scientific history.

Thus, it is not surprising to learn that he did not focus on education. Nor did he analyze any interrelationship between education and rebellion. And, finally , his focus remained limited to the 1920s.

Marjorie Becker, in her book Setting the Virgin on Fire: Lázaro Cárdenas, Michoacán Peasants, and the Redemption of the Mexican Revolution, focused on the interrelationship between agrarian reform and the socialist education program put forth by president Lázaro Cárdenas. ${ }^{13}$ My work covers the years prior to Lázaro Cárdenas' presidential term and events not related to agrarian reform. ${ }^{14}$ She focused on different views about curriculum issues but did not investigate how this curriculum expressed itself in a culture of local violent expression. ${ }^{15}$

Adrian Bantjes sought to shed light on Cárdenas and his relationship with

\footnotetext{
12 Jean Meyer, The Cristero Rebellion: The Mexican People Between Church and State, 1926-1929, (Cambridge, Cambridge University Press: 1976).

${ }^{13}$ Marjorie Becker, Setting the Virgin on Fire: Lázaro Cárdenas, Michoacán Peasants and the Redemption of the Mexican Revolution, (Berkeley, University of California Press: 1995), 1.

${ }^{14}$ Ibid.

${ }^{15}$ Ibid., 123.
} 
campesinos of states in Mexico in his book, As If Jesus Walked on Earth: Sonora

Cárdenismo, and the Mexican Revolution. In a small section he payed some attention to agrarian reform and how it intersects with the secular education program." ${ }^{16}$ He too kept his focus on the discussion of the ideological and theoretical issues without examining the conditions on the ground and people's culture in detail. ${ }^{17}$

How do these themes differ by state, rural environment, and urban setting? One question is the importance of gender in this environment. Were female teachers victims of violence more than their male counterparts? The following pages attempt to offer a first illumination of this issue.

An outstanding aspect was the relative absence of political negotiation and its replacement with violence. In Durango and Jalisco, state building was not limited to politics but included violence in the educational sector and folk religion.

Newly found sources allow for the first time a comparative analysis between primary, secondary, and higher education.

A third question covered deals with the current stage of knowledge, suggesting that the period between 1924 - 1939 represents a period influenced by one war over religious issues, also referred to as the Cristero War. Perhaps our chronological understanding has to be adjusted. Finally, I ask if contemporary chronological structure serves a more nuanced order of events.

\footnotetext{
${ }^{16}$ Adrian Bantjes, As If Jesus Walked on Earth: Cardenismo, Sonora, and the Mexican Revolution, (Wilmington Delaware, Scholarly Resources Inc.: 1998), xi.

${ }^{17}$ Ibid. , 18.
} 
Anti - clericalism beginning in the late 1920s initiated the violent backlash involving priest activism and the start of a "new" phase of the Cristero War that continued through the entirety of the 1930s. The closing of clandestine schools in the late 1920 s and early 1930 s added fuel to the already unstable fire that was still burning in the state of Jalisco.

Attacks on priests and churches sparked the second phase of the Cristero War. The anti - clerical laws limited the number of priests and churches allowed in each state and violated the Modus Vivendi of 1929. The official Constitutional law failed to guarantee freedom of worship under the President Portes Gil. The anti- clericalism codified in congress after the Mexican Revolution was perceived in a particularly negative way in Jalisco due to a large presence of indigenous Catholics who had and would continue to fight against these constitutional laws, especially when it came to the education of the youth of the state.

Many incidences of violence took place during the second phase of the Cristero War, which were aimed at secular school - teachers. These attacks were in many cases promoted by priest activists. The separation between church and state on the level of learning became the stage for rebellion in Jalisco.

The reader might be surprised by the small amount of monographs about Mexican education. My work attends to add to these five texts and the acute amount of texts dealing with Mexican education on a state and regional level.

Chapter two of my thesis and research is focused on Durango and the interrelationship of the state's culture of violence, primary and secondary 
education, religion, and the political context. Violence, primary and secondary education, religion, and the politics became interrelated in Durango during the years of 1930- 1939 following the Cristero Rebellion.

Much of the violence that occurred in Durango during the 1930s involving the Cristero rebels was directly linked to the introduction of secular education, as it threatened the Catholic education and way of life for the folk people of the state.

Chapter three focuses on Jalisco and deals with the state's culture of violence, the church and state relationship, the primary and secondary education situation, but also university higher education situation. Again, I research how its clash created violence.

The Cristeros used a variety of weapons, ranging from explosives like dynamite to Mausers and tommy guns. The "new" phase of the Cristero War was focused in the area of southern Durango near the border of the state of Jalisco called the Los Altos region.

Similar to the situation in Durango many priests served as activists during the "new" phase of the Cristero War concentrated their attacks on secular educators. In both states priests took the role of religious leaders and activist rebel leaders. Like the situation in Durango, in Jalisco religious or clandestine schools were being closed and priests were being put out of a job. These closures caused much anger and frustration by the folk Catholic populations of 
both states. The tension between secular and religion based education was seen throughout the primary, secondary, and higher education realm. 


\section{Chapter 2: Durango}

The state of Durango is located in the northwest of Mexico. It is the fourth largest state and borders to the north on Chihuahua, to the north- east Coahuila, to the south- east by Zacatecas, to the South- west by Nayarit and Jalisco, and to the west by Sinaloa.

Nature shaped this state far more than human beings. Durango is very mountainous and is made up mainly of forests. The mountain range Sierra Madre Occidental takes up two thirds of the state. It also is home to deserts and vast wilderness. For a long time Durango could be reached only by train from Mexico City. Therefore, it should not surprise that, in 1930, it had Mexico's second - lowest population density. Only Baja California del Sur counted fewer inhabitants. Mexico City politicians had difficulty dominating this distant area.

In order to understand Durango's particular story of the 1930s we need to place it into the larger national historical context of that era. For our story that is the fact that the Mexican Revolution (1910-1920) had created the worlds most stringent anti - Catholic legislation backed by a constitution. ${ }^{18}$

In the immediate years following the Mexican Revolution it was up to new President Alvaro Obregon to rebuild the nation. ${ }^{19}$ Yet despite his effort, Mexico remained a nation of regions that was anything but united. ${ }^{20}$ The economy continued to suffer, fighting continued, and politics remained in disarray. Obregon

\footnotetext{
${ }^{18}$ Joseph A. Stout Jr. Spies, Politics, and Power: El Departamento Confidencial en Mexico, 19221946, (Fort Worth, TCU Press: 2012) 30.

${ }^{19}$ Ibid. , 30.

${ }^{20}$ lbid.
} 
knew that a strong central government and military control was necessary to bring all of Mexico's diverse regions under Mexico City's control. ${ }^{21}$ Part of his flaw to achieve political stability was to improve economic and social opportunities by modernizing the country. ${ }^{22}$ This also pertained to rural Durango, where these aims remained difficult to implement.

Plutarco Elias Calles became President of Mexico in December of $1924 .^{23}$ Calles, like Obregon, believed that Mexico needed a strong centralized government to become modernized. ${ }^{24}$ But Calles also saw the Catholic Church as a representation of a backward looking tradition that needed to be overcome. For Obregon the Catholic Church had been more an integral part of the nation. ${ }^{25}$ Calles imposed anti - Catholic policy on all regions.

In Durango regional caudillos emerged and led rebel groups in response to his anti- clericalist platform. One of these was the Cristeros. ${ }^{26}$ Due to the anti clerical platform of Calles the Cristeros emerged as an anti - government group throughout Durango. ${ }^{27}$ According to American historian Joseph A. Stout, the Cristero rebellion was a pro - Catholic movement that lasted until 1929. ${ }^{28}$

\footnotetext{
${ }^{21} \mathrm{Ibid}$.

22 Ibid.

23 Ibid. , 40.

24 Ibid. , 33

${ }^{25} \mathrm{Ibid}$.

${ }^{26}$ Ibid. , 50.

${ }^{27}$ Ibid. , 51.

${ }^{28}$ Ibid., 52.
} 
In 1929 the Modus Vivendi Law was created as an agreement between Mexican President Portes Gil and the Vatican. ${ }^{29}$ Thereafter, the Mexico City government amended the 1917 constitution with Article $130 .{ }^{30}$ It limited in a most radical way the number of priests that could live in a pre - assigned geographical area and serve its populations. ${ }^{31}$ In essence, instituting article 130 was a national revolutionary political act to further break the power of the Catholic Church over regional Mexican daily life. It targeted the maintenance and reproduction of Catholic folk syncretism. Also in Durango it challenged farmers and village residents and their way of life.

Second, in addition to attacking the folk traditions of Durango, these laws were an attack on the remaining autonomy of the Catholic Church over regional bonds between church and society. In Durango such a challenge had not been experienced previously.

Durango was governed by state Governor Señor Enrique Calderón. In 1934 incoming president Lázaro Cárdenas had appointed him. It was Calderón’s task to govern the state in such a way that Mexico City's revolutionary government could control it. Thus he inherited the challenge to manage the imposition of article 130. Part of this task was to say and enforce who controlled the education of Durango's youth.

\footnotetext{
${ }^{29}$ British National Archives, Mexican Religious Activities of the 1930s, FO 547/56/26.

${ }^{30} \mathrm{Ibid}$.

${ }^{31}$ Ibid.
} 
Once he started his role as governor Calderón proceeded to hand select individuals for his cabinet. ${ }^{32}$ Most of the men picked were his friends arriving with him from Mexico City. ${ }^{33}$ Next he picked who would represent Durango as PNR ${ }^{34}$ representatives in La Capital's Chamber of Deputies. ${ }^{35}$ Thereafter, he and his entourage determined politics purposely excluding individuals who represented the traditional regional way of life. Thus, also in regard to the imposition of educational policy, he could count on a united front. Calderón acted as Durango's political boss.

Calderón was known to be corrupt. His main corrupt activity was using public funds for his own personal use.$^{36}$ One political observer classified the political mood of the state in 1934 "as [being] in ferment." ${ }^{37}$

Those peasants who wanted alternatives did not receive representation in Mexico City. ${ }^{38}$ Calderón was therefore unpopular with Durango's citizens. ${ }^{39}$ There was no way to have one's voices heard and translated into civil political action. Would it have even mattered?

Scientific literature says that Justo Sierra initiated state education for the nation. ${ }^{40}$ But newly found sources suggest that this nation building reform from

\footnotetext{
32 Ibid.

${ }^{33}$ Ibid.

${ }^{34}$ Partido Nacional Revolucionario or National Revoultionary Party.

${ }^{35}$ Ibid.

${ }^{36}$ Ibid.

${ }^{37}$ NAUS, DOS, 59, M1370, Internal Affairs of Mexico 1930-1939, 12,812.00/DURANGO/202.

${ }^{38}$ Ibid.

${ }^{39}$ Ibid.

${ }^{40}$ Justo Sierra, The Political Evolution of the Mexican People, (Austin, University of Texas Press: 2014).
} 
the 1880s never had taken hold so much further northwest of Mexico City. Not even in 1930. Education on all levels remained in the hands of priests and a Catholic educational worldview.

Revolutionary anti - Catholic laws had reached Durango. Officially, the Mexico City government had decreed that nine priests were allowed to serve Durango's population. ${ }^{41}$ And yet more than six times that number was counted by observers. ${ }^{42}$ In the states' 160 churches, 60 priests were taking care of parishes. ${ }^{43} 40 \%$ were served. $60 \%$ had been forced to remain empty or shut down.

Priests in the state of Durango were not hesitant to function outside and against federal laws. For example, it was stated that, "It is reported that the full quota of Catholic priests have complied with the law by registering, and apart from the number provided for by law, there are approximately 50 priests more functioning clandestinely, but with the knowledge of state authorities, in the 150 to 160 Catholic churches in this state." ${ }^{44}$ At least 100 priests were functioning outside of the federal law due to restrictions in numbers set forth by the government in Mexico City under the Mexican Constitution of 1917.

Also it is important to realize that many priests did double duty: as religious officials and as educators. Thus increasing or decreasing the number of

\footnotetext{
${ }^{41}$ NAUS, DOS, 59, M1370, Internal Affairs of Mexico 1930-1939, 12,812.00/DURANGO/243, Political Report, August 1937.

42 Ibid.

${ }^{43} 50$ of them had even registered.

${ }^{44}$ NAUS, DOS, 59, M1370, Internal Affairs of Mexico 1930-1939, 12,812.00/DURANGO/247, Political Report, November 1937.
} 
priests also effected if and what Durango's students could learn. Interestingly Durango's political culture had made room for a give and take compromise. In Mexico City Lázaro Cárdenas did not order Calderón to impose rule by the book. $^{45}$

Following the closures of many churches and Catholic schools there was an attempt by the government in Mexico City to reopen a small amount of Catholic churches throughout the country. However this attempt did not satisfy local Catholic communities. It was stated that, "The reopening of approximately 3,000 Catholic churches in this country by the Federal Government caused a very favorable impression in this state, which is very strongly Catholic, but as was expected, they are not satisfied with this action on the part of the government but want the religious situation restored to where it was prior to the religious difficulties of $1926 . " 46$

The divide between church and state over education in Durango was beginning to intensify in the 1930s. In 1934 the situation became unstable. Priests acted more adverse to secular education and were preaching in favor of defiance of secular schooling. ${ }^{47}$ Even Durango's archbishop threatened Catholic parents and demanded that they keep their children out of secular public schools or else the church would not grant them absolution. ${ }^{48}$

\footnotetext{
${ }^{45} 30$ unregistered schools in Durango.

${ }^{46}$ Ibid.

${ }^{47}$ NAUS, DOS, 59, M1370, Internal Affairs of Mexico 1930-1939, 12,812.00/DURANGO/242, Political Report, July 1937.

${ }^{48}$ Ibid.
} 
For these Catholic leaders and folk people of the state of Durango, going to a public school where secular learning was taught instead of the catechism represented an insult to their religious practices. Those who did send their children to secular schools were seen as outcasts among their family and friends. Parents were caught in the widening split between church, state, and education.

The choice to send their children to a clandestine private school, as opposed to a secular school, was one that most Catholic parents in the state of Durango felt was theirs to make, neither the government of Mexico City nor the heads of the state should decide what their children should be learning. ${ }^{49}$

The government policy forced educational decisions to become conscious decisions. For parents, what had been unquestioned custom before now required taking a painful stance to defy either spiritual or political authorities. Suddenly parents stood in a chasm with threatening consequences from either side.

On one side the archbishop threatened parents with the denial of absolution of the entire family if they became disloyal to church education. ${ }^{50}$ This was the threat of spiritual limbo, an impossible situation, far worse than any denial of education.

On the other side the government threatened to punish parents who continued to send their children to Catholic school by jailing them and, therefore,

\footnotetext{
${ }^{49}$ NAUS, DOS, 59, M1370, Internal Affairs of Mexico 1930-1939, 12,812.00/DURANGO/242.

${ }^{50}$ NAUS, DOS, 59, M1370, Internal Affairs of Mexico 1930-1939, 12,812.00/DURANGO/242.
} 
separating them from their children. ${ }^{51}$ This issue will concern us again when we deal with the realization of the same question in the state of Jalisco.

This chapter will examine in detail the many complex components Durango's culture of violence.$^{52}$ Who were the individuals and social groups clashing in Durango?

\section{A. Two Sides of a Regional Culture of Violence}

To gain a deeper understanding the chapter is divided into two parts. One part will examine what anti-government rebels did. Their actions will be compared to the responses carried out by the troops of Mexico City inside Durango's military zone number 10 . We begin by identifying where the two sides met and clashed.

Rebels acted most strongly in the southern and southeastern part of the state. In the southeast near Mezquital rebel activity was so sustained that secular teachers had to be withdrawn. A second center of activity was located around the city of Durango, particularly its northern part. ${ }^{53}$ One source tells us "... at the end of the month there were now several new bands of armed men who called themselves rebels to the north and the west of the city of Durango, and their number appears to be increasing." ${ }^{54}$ Two groups of rebels were working in

\footnotetext{
${ }^{51}$ NAUS, DOS, 59,M1370, Internal Affairs of Mexico 1930- 1939,12,812.00/DURANGO/191.

52 NAUS, DOS, 59, M1370, Internal Affairs of Mexico 1930-1939,12,812.00/DURANGO/191. Here a source described how religion, politics, and education were connected in the state of Durango came in the form of a meeting on March 1, 1936.

${ }^{53}$ NAUS, DOS, 59, M1370, Internal Affairs of Mexico 1930-1939, 12,812.00/DURANGO/191, E.W. Eaton American Vice Consul in Durango, March 1936.

${ }^{54}$ Ibid.
} 
the southeastern region of Durango. ${ }^{55}$ A location mentioned was an area called Loma Quebrada. Finally southeastern mountains were also important. There rebel leader Vázquez fought against federal troops of the $15^{\text {th }}$ battalion." ${ }^{\text {"56 }}$

And yet in those geographical spaces rebels did not act everywhere. To the contrary, they were selective where they attacked government representatives. If available they preferred the cover of a village or at least the presence of a building.

Interestingly, not one case is known where rebels engaged the Mexican army in an open battle in the open field. In contrast the government tried to bring the fight to rebels wherever they could find them, under any circumstance. In one case even a vehicle on the road, with rebels inside, became an area for a fight.

Who were the rebels? In these areas lived and fought three clearly identifiable groups: small farmers, peasants, and Catholic clergy. Clergy was seen as having a higher social rank but nevertheless fought as equals for regional Durango culture. Jointly peasants, small farmers, and clergy defended their folk life and opposed the modernizations imposed by Governor Calderón. But not everybody was involved in activity against the government. Their central social political form was the male rebel gang. Not a single woman was mentioned in the sources as a combatant. Until news sources reveal Cristero

\footnotetext{
${ }^{55}$ Ibid.

${ }^{56}$ Ibid.
} 
Soldaderas, one has to be content with the currently available evidence suggesting that the anti-government gangs were staffed exclusively by men.

At all times the rebel gang was a voluntary fighting force, an expression of a rolling culture of violence thrust in any form possible against government policy. The Cristeros fought as highly motivated lay volunteers. They never gathered as an organized professional army unit.

The size of these gangs was that of a remarkable $75-100$ people. $^{57}$ Rebels groups north as well as west of the city counted 75 members. ${ }^{58}$ These larger groups consisted of smaller sub factions held together by a bond of friendship but also shared origin from the same village.

Recruitment into the group was ongoing. In particular, as the larger group experienced losses smaller units rebuilt themselves.

After a battle larger gangs, sometimes disbanded into smaller subgroups until it was time to gather again and form into a larger section and attack the next urban educational setting. In essence a gang was a part of a fluid volunteer fighting force. Never was it a systematically built professional fighting force motivated by pay. Because of the voluntary nature of group formation motivation to fight was high. Rebel bands did not give up easily and were willing to carry on a very personal war. Once source indicated:

\footnotetext{
${ }^{57}$ Many of these men had been a part of the Cristero Rebellion of the 1920s. Their culture of violence was centered on the opposition to modern, revolutionary state - led, secular education that was accepted in Mexico City during the 1930s. The Cristero rebels were predominately of folk Catholic background and lived in rural areas of the state of Durango.

${ }^{58}$ NAUS, DOS, 59, M1370, Internal Affairs of Mexico 1930-1939, 12,812.00/DURANGO/191, E.W. Eaton American Vice Consul in Durango, March 1936.
} 
"At the end of the month there were now several new bands of armed men who called themselves rebels to the north and the west of the city of Durango, and their number appears to be increasing.."59

The same letter described how two groups of rebel men with guns and ammunition were working in the southeastern region of Durango. ${ }^{60}$ They consisted of approximately 75 men. ${ }^{61}$ In an area called Loma Quebrada another group led by Vázquez in the southeastern mountains fought against federal troops of the $15^{\text {th }}$ battalion." 62

It is worthwhile to take a look at social composition of gangs. It was not limited to farmers but included, sometimes, priests. This struggle was so intense that social and professional hierarchies of civilian life ended. The rebel gangs provided a place for peasants, farmers, and renegade priests. One source identified:

Reverend Rafael Aguilar, a young Catholic priest born in the state of Zacatecas but who studied for the priesthood in a local school and was ordained in this city about two years ago; a younger brother of his, and even others who are not so well known. ${ }^{63}$

Within the gang priests sometimes, but not always served as spiritual leaders. Their physical presence and participation signaled to the common fighter that the defense of culture was very much endorsed by spiritual elites and

\footnotetext{
${ }^{59}$ Ibid.

${ }^{60}$ Ibid.

${ }^{61} \mathrm{Ibid}$.

62 Ibid.

${ }^{63}$ Ibid.
} 
by inference it was assumed by the distant Vatican in Rome, Italy. A gang could be a place where bonds of priests and parish were deepened and celebrated. Leadership could also come from a farmer who was a good fighter or a priest. A third source was higher educated secular leaders who distinguished themselves by holding the equivalent of today's B.A., called Liciencatura. Well into the 1980s' a liciencatura remained a mark of educational distinction and entitled an individual to a higher social rank with increased decision - making power. One source named Licienciado Villagran. He might have used a nombre de guerre. Semiofficial channels identified him as Licenciado Raul de Leon who, as ranking rebel forces member, worked as head of propaganda and general adviser. He was considered to be one of the most active leaders of the rebel movement in this state. ${ }^{64}$ After identifying the locations of clashes and social composition we need to ask what modes of transportation rebels used to travel from the open field to Durango City and other villages.

Most of the time the rebels, of course, used horses to reach their location to inflict violence. And yet, on occasion modernity in the form of a car was mentioned in the sources. ${ }^{65}$ Well to do individuals who could afford an automobile helped in transporting fighters across distances. Near the Parque

\footnotetext{
64 Ibid.

${ }^{65}$ NAUS, DOS, 59, M1370, Internal Affairs of Mexico 1930-1939, 12,812.00/DURANGO/200, E.W. Eaton American Vice Consul in Mexico.
} 
Guadiana on the way to the city of Tepias, government soldiers stopped a car carrying five Cristero rebels with arms inside. ${ }^{66}$

Next we take a look at their armament. Sources revealed that the term "weapons" was not limited to iron tools designed to draw blood. In addition to guns causing severe bodily harm rebels used a mix of tools of violence, symbolic representations, and non - violent evasive tactics. We will begin by looking at firearms first. Cristero rebels used three different types of firearms. They were Mausers, pistols, but also Thompson machine guns. For example on the evening of May 19, 1936 five Cristeros were apprehended by a small group of soldiers, near the Parque Guadiana on the way to the city of Tepias, hopped out of the vehicle and began shooting at the soldiers. ${ }^{67}$

Second the terms weapons meant the use of explosives. In the $10^{\text {th }}$ military zone Lic. Raul de Leon, the rebel leader, was killed carrying explosives. ${ }^{68}$ After the attack the Durango government was able to confiscate the vehicle the rebels had been apprehended in; and: "Upon searching the automobile in which these rebels were traveling it was found that they had four dynamite bombs, 10 sticks of dynamite, fuses, wire, and an electric battery for exploding these bombs". 69

Explosives were relatively easy to procure because mines in northern Durango, Chihuahua, and Sonora needed dynamite to drive shafts into the

\footnotetext{
${ }^{66}$ Ibid.

${ }^{67}$ Ibid.

68 Ibid.

${ }^{69}$ Ibid.
} 
mountains. Thus dynamite sticks could easily be bought and carried southward into territory of rebellion. Dynamite was also a regular staple in supply stores near mines. It also mattered that a few sticks of dynamite were far cheaper than the purchase of a gun and cartridges. ${ }^{70}$ Lic. Raul de Leon, the rebel leader, was killed carrying explosives. ${ }^{71}$

Fourth, weapons meant tools to win people's hearts and minds. The worldview of individuals and rural society in general was attacked through the use of propaganda. In one car was found:

...A large amount of seditious literature signed by Lic. Raul de Leon as Jefe de la Liga de Defensa de la Libertad Religiosa, (Chief of the League for the Defense of Religious Freedom), as well as a considerable amount of personal correspondence belonging to Lic. De Leon addressed to and received from Catholic priests and private individuals in different parts of the country...

Fifth, usage of century old religious symbols and their appeal to tradition was used. Embroidered, woven or painted the religiously symbolic image of the Virgin of Guadalupe was the most chosen image. This was not just a simple waving of a flag but an invocation of ancient forces. The Virgin of Guadalupe was a four hundred year old Catholic patron saint of the colonial past. And before then the location where the shrine and church of the Virgin of Guadalupe stood was home to the temple of Tonanztin, one of the highest female powers of Nahuatl spiritual cosmos. Durango's ranchers and priests "armed" themselves

\footnotetext{
${ }^{70}$ Charles H. Harris III, Louis R. Sadler, The Secret War in El Paso: Mexican Revolutionary Intrigue, 1906- 1920, University of New Mexico Press: 2009, 87.

${ }^{71}$ Ibid.
} 
with the spiritual energy of two folk worldviews against the Mexico City's still emerging modernist symbolism and revolutionary education.

I have argued in favor of the existence of an entire culture of violence, not just a few battles. The rebellion by folk Catholics consisted of the use of a variety of almost ritualistic activities that are worthwhile to investigate.

Fighting consisted of violent but also non-violent subversive activities. Attacks were not just simple outburst of aggression. Instead they consisted mostly of destroying of locations where the new revolutionary curriculum could be taught.

We can differentiate between aggression against buildings, people, and storage of resources to replenish rebel strength.

First buildings were attacked. Most of them were schools where newly sent secular teachers transmitted revolutionary ideas. In Soledad a group of 102 rebels were led by Francisco Garcia into an agrarian village and burned a school. ${ }^{72}$ These rebels carried a large banner with the image of the Virgin de Guadalupe on it and screamed "Viva Cristo Rey" and "Death to Calles". ${ }^{73}$

Secular teachers who were not from Durango and been dispatched by Aarón Sáenz, Mexico City's Secretary of Education to the rural areas had a higher likelihood of being attacked. While attacking teachers farmers shouted intense disdain for those who were trying to make secular education in their country side a permanent feature.

\footnotetext{
${ }^{72}$ NAUS, DOS, 59, M1370, Internal Affairs of Mexico 1930-1939, 12,812.00/DURANGO/202, E.W. Eaton to Secretary of State, May 29, 1936.

${ }^{73} \mathrm{Ibid}$.
} 
Sometimes attacks were designed to only scare teachers so that they would run away. An attack against teachers in the district along the Durango Tepehuanes railway, from the northern and from the southeastern parts of Durango, made teachers flee from buildings. ${ }^{74}$ In Soledad a secular teacher was attacked with an intensity that almost caused his death. But he too was allowed to escape. ${ }^{75}$

It is important to realize that rebels did not limit violence to schools and teachers. In addition, they chose to attack local and regional peasants who were benefiting from Mexico City's newly imposed land distribution program. There Mexico City's government had created so-called agrarista communities. Cristero rebels saw in their presence and growth just another manifestation of Mexico City's socio-political forms antithetical to what local culture in Durango should consist of. Just like secular schools and teachers, this alien form of landownership originating out of the revolution was physically attacked.

Previously, these peasant communities had received a communal revolutionary land grant, and they were considered agrarian allies of new political forms introduced by governor Calderon.

Finally rebels attacked simple farms without any connection to policies from Mexico City. Instead, they held larger herds of horses and mules, that rebels needed to sustain their hit and run campaigns. In one attack rebels stole 35

\footnotetext{
${ }^{74}$ Ibid.

${ }^{75}$ NAUS, DOS, 59, M1370, Internal Affairs of Mexico 1930-1939, 12,812.00/DURANGO/202, E.W. Eaton to Secretary of State, May 29, 1936.
} 
horses and mules from a farm that had nothing to do with old or new forms of education or land ownership. ${ }^{76}$ In a second conflict near Nuevo Pueblo "an engagement took place between troops of the $40^{\text {th }}$ Battalion, headquarters at $\mathrm{El}$ Salto, Durango, and a group of Cristeros [...] at Laguna Prieta and Puerto Tecolote, Durango. ${ }^{77}$ Surviving fighters escaped with provisions, weapons, and ammunition. $^{78}$

The local culture of attack also included periods when fighting seemed to have lost religious purpose. Individuals who were Cristeros during one longer stretch of civil war seemed to have regressed to the level of banditry. Despite the fact that six of the Cristeros in this particular group were killed there were many who escaped and most likely regrouped to continue their rebellion:

There have been rumors for some time of bands of Cristeros raiding and looting the small ranches in the southern part of the state, but this is the first engagement of any importance with Federal troops. These Cristeros are normally small farmers who cultivate small tracts of lands in the mountains for their livelihood and when the prime necessities of life become scarce they take to looting and raiding for a living, as there is not much of anything else in the sector in which they live for them to do. They are nothing more than a group of bandits and highwaymen banded together for greater protection and call themselves Cristeros partly in order to receive assistance of provisions and money from some of the more fanatical Catholics of this city and adjoining villages, and to avoid the stigma of being known as bandits. ${ }^{79}$

\footnotetext{
${ }^{76} \mathrm{lbid}$.

${ }^{77}$ NAUS, DOS, 59, M1370, Internal Affairs of Mexico 1930-1939, 12,812.00/DURANGO/245, E.W. Eaton to Secretary of State, November 3, 1937.

${ }^{78}$ Ibid.

${ }^{79}$ Ibid.
} 
Not all battle reports allowed obvious interpretation. The political report for Durango during the month of August 1936 explained that, "It appears that bandits (or 'Cristeros' as reported by the local press) attacked a group of peons near Santiago Bayacora in the state of Durango about July 31, 1937. Five of the peons were killed in the encounter." ${ }^{180}$

Perhaps future research in archives of local churches can add further reasons and insights into structure of attacks.

A rebel attack, however, did not mean the end of matters. Rather it represented a spike of activity in a longer stretch of rituals like sequences that added up to a wave like effect of events. It is worthwhile to take a closer look at outcomes.

Even though intense physical exchanges destroyed building and sometimes killed individuals the records show that the culture of violence offered five endings: death, surrender, evasion, regrouping. In addition there existed a non - violent realm where the outcome consisted of re - founding schools at clandestine sites. There the folk based curriculum was relocated to and revived.

There were five outcomes of confrontations. The first outcome was death, but one could also die after a battle where a rebel had been apprehended. For

\footnotetext{
${ }^{80}$ NAUS, DOS, 59, M1370, Internal Affairs of Mexico 1930-1939, 12,812.00/DURANGO/243, Political Report, August 1936.
} 
example, "a skirmish with a small garrison of Federal troops ensued resulting in 6 of the Cristeros being killed and an unknown number of wounded." ${ }^{81}$

But one could also die after a battle where a rebel had been apprehended. Then government soldiers took fighters to the edge of town and executed them on the spot. ${ }^{82}$ In one incident ten rebels were executed after an arrest. ${ }^{83}$ This fate was possible for individuals regardless of social rank or whether they were parishioners or priests. Señor Alfonso Díaz Gonzales was executed. Also executed was Reverend Rafael Águilar, a young Catholic priest born in the state of Zacatecas. Social rank made no difference for life or death once a rebel was apprehended. ${ }^{84}$

Execution might not be limited to a rebel. On occasion it extended to one's entire family. Even children were not spared. ${ }^{85}$ In one house Mora and his closest advisor, Pablo Reyes, were found. They were killed on the spot. Next Mora's wife and his children also suffered death. ${ }^{86}$ The application of repression was brutal, decisive and across the board. Execution and murder of the entire family was not the end of it. In order to make a point that individual leaders were

\footnotetext{
${ }^{81}$ NAUS, DOS, 59, M1370, Internal Affairs of Mexico 1930-1939, 12,812.00/DURANGO/191, E.W. Eaton American Vice Consul in Durango, March 1936.

82 U.S. Military Intelligence Reports: Mexico 1919-1941, Reel 2, G-2 Report no. 7268- 3020- b, Lawrence Ecker, July 5, 1936.

83 Ibid.

${ }^{84}$ Ibid.

85 Ibid.

${ }^{86}$ Ibid.
} 
no longer available, government troops displayed the corpse in a ritualistic display in one case in Durango city. ${ }^{87}$

A surprise finding was that rebels who were met by government soldiers did not automatically die. Surrender was a second accepted alternative. One example of surrender is a case in Canatlán. Francisco Garcia was from Canatlán and became a leader five months ago. ${ }^{88}$ It was there Garcia asked for safe haven. ${ }^{89}$ He requested a meeting with Colonel Alberto Bello Santana, commander of the $19^{\text {th }}$ regiment and chief of Canatlán sector, to negotiate a surrender of the members of his rebel gang. ${ }^{90}$ The meeting was held near Rancho Colorado in the mountains. ${ }^{91}$

Señor Simplicio Ruíz first spoke with Garcia and accepted Garcia’s men’s surrender and ordered federal troops to halt attacks on the rebels. They had been outnumbered in the mountains. ${ }^{92}$ In order to emphasize his case Santana claimed that twenty -three men had surrendered in Canatlán and that 39 men had surrendered in total. ${ }^{93}$ He said a few were missing. ${ }^{94}$ The rebels who surrendered were told by Garcia to hand over their weapons. ${ }^{95}$

${ }^{87}$ Ibid.

${ }^{88}$ Ibid.

${ }^{89}$ U.S. Military Intelligence Reports: Mexico 1919-1941, Reel 2, G-2 Report no. 7268- 3020- b, Lawrence Ecker, July 5, 1936.

${ }^{90}$ Ibid.

${ }^{91}$ Ibid.

${ }^{92}$ Ibid.

93 Ibid.

94 Ibid.

${ }^{95}$ Ibid. 
A second case was the surrender of rebel leader Federico Vázquez.

Vázquez did not surrender because he was scared that military leaders would kill him and his rebel followers. ${ }^{96}$ Vázquez demanded proof that he and his followers would not be injured if they did surrender. ${ }^{97}$ Vázquez did not surrender with any followers, which meant they could have possibly still been fighting the Cristero war in Durango. Due to the mountainous terrain of Southern Durango it was not that difficult for these rebels to find cover in the caves and rural areas in which they lived.

Rebel groups did not seek violent clashes with government troops at all costs. Rather they evaluated momentary power balances and, if it was unfavorable, decided to evade government troops.

Evasion could also mean to stop fighting for a while. Traditionally this had been tied to corn planting or livestock breeding events such as lamming or sheep shearing. Thus commanders told Mexico City that General of Brigade Lucas Gonzales Tijerina, chief of the $10^{\text {th }}$ military zone, reported $[\ldots]$ that there are no rebels in the state at this time; that since the engagement reported in the last month's review some of the small bands have dispersed and others have returned to the State of Nayarit from where they entered the State of Durango several weeks ago." ${ }^{\prime 98}$

\footnotetext{
${ }^{96}$ NAUS, DOS, 59, M1370, Internal Affairs of Mexico 1930-1939, 12,812.00/DURANGO/215, Political Report, October 1934.

${ }^{97}$ Ibid.

${ }^{98}$ NAUS, DOS, 59, M1370, Internal Affairs of Mexico 1930-1939, 12,812.00/DURANGO/242, E.W. Eaton to Secretary of State, July 31, 1936.
} 
Such report might not mean an actual absence of fighters rather dispersed groups could have possibly regrouped into new groups. These new groups went undetected by federal government officials due to a larger fighting area created by geography.

Finally, death, surrender, and evasion were sometimes merely a tactical step toward regrouping. One source reported that, "The surrender of Francisco Garcia with his band, an the death of J. Trinidad Mora and Pablo Reyes, leaves Federico Vázquez of the rebel leaders formerly active in this state, and he is reported to have only a small number of men." ${ }^{\text {"99 }}$ More men could still be in rebellion there however this may be the only amount of rebels that the federals noted because the others were perhaps in hiding in the rural mountainous regions of Southern Durango.

Rebel activity included a second side that was not just aggressive but aimed to move folk activities underground. Once underground Cristeros reopened activities inside a follower's home.

The most prominent reaction to the creation of secular school with teachers from Mexico City was to, first, withdraw ones children from it. Then parents reenrolled the children in a newly founded private but clandestine school:

The 'Justo Sierra', formerly one of the leading private schools of this city, but taken over about two years ago by a 'cooperativa' of teachers, was closed during the month by the Federal Department of Education for failure to comply with Article 3 of the Constitution as amended. It is reported that since the religious situation is now practically to where it was

${ }^{99}$ Ibid. 
prior to the latest religious difficulty, more children than ever will be sent to clandestine private schools when the next school year opens. ${ }^{100}$

In the case where authorities forced children to attend secular school during the week, the Cristeros used weekends to teach their values and content in clandestine schools. It is remarkable that priests had been acting as teachers of catechism in small groups on the weekends not challenging the public schools, and the authorities did not intervene. ${ }^{101}$ It was stated that, "Since the better class of Mexicans usually do not care to send their children to the public schools, mainly on account of the teaching of socialism, a number of schools in private homes have been functioning for some time in a clandestine manner. It is reported that about thirty unregistered schools in the city of Durango."102

Unregistered schools being held in the homes of the priests were not an unusual thing because this way the schools could be created and led however the priests felt necessary. It gave them control over the materials the schools would use to teach the youth of the state. It also allowed them to continue to practice despite restrictions placed on them by the Constitution of 1917.

There existed extreme dissatisfaction with the federal education system:

The people in general appear to be satisfied with the religious situation in this state insofar as the churches are concerned, but they are not at all satisfied with the state law which requires that teaching be based on Socialism, which feeling is being augmented by the clergy. This has resulted in about 30 private schools functioning in this city under direct

\footnotetext{
100 Ibid.

${ }^{101}$ NAUS, DOS, 59, M1370, Internal Affairs of Mexico 1930-1939, 12,812.00/DURANGO/244, StephenC. Worcester, American Vice Consul, Political Report, September 1937. 102 Ibid.
} 
supervision of priests and ex- nuns. Several of these schools were closed the latter part of September and during early October. This has caused considerable dissatisfaction among Catholic parents of children of school age, and has resulted in the Archbishop going to Mexico City for conference with the Hierarchy there where he expects to remain for several weeks. ${ }^{103}$

Although the people may have to be to some extent satisfied with the Catholic community and the state government there was an obvious disagreement when it came to the question of religious reform with exclusion of the Catholic way of education in exchange for the secular education that was prescribed in Mexico City and being pushed upon the people of rural Durango.

B. Government Side of the Culture of violence in Durango

When we use the term government side of the culture of violence we mean the presence of governmental soldiers or secular teachers. Those two groups were the face of the government in the region, never the politicians close to governor Calderon.

Often soldiers and secular teachers worked hand in hand. Federal army troops reacted by trying to protect lives of the teachers. Protecting teachers most often meant supplying them with arms.

One source described, "Due to the existence of armed bands in that area of the city and rural teachers located in the northern part of the city, teachers were given arms and ammunition as well as being informed how to organize

\footnotetext{
${ }^{103}$ NAUS, DOS, 59, M1370, Internal Affairs of Mexico 1930-1939, 12,812.00/DURANGO/246, Political Report, October 1937.
} 
agrarian people to come to their aide if there is an attack on them. ${ }^{104} \mathrm{~A}$ second report remarked "....as there are number of rebels in the southeastern part of the state, the school teachers in the Mezquital section have been given vacations by the Director of Education with instructions to come into Durango and the Director of Education has refused to accept them, except from female teachers. "105

Another smaller group of rebels assisted the Cristeros but were badly outmanned by the federal troops. ${ }^{106}$ Many rebels had been killed and taken to the hospital. ${ }^{107}$

Despite their anger and the new phase of the Cristero war, these rebels were still very outnumbered and with limited weapons and ammunition in comparison with the federal troops and leaders they often battled with. This meant federal troops had the advantage when fighting occurred in the city but not in the mountains.

On the evening of May 19,1936 a small group of soldiers were situated near the Parque Guadiana on the way to the city of Tepias stopped a car that had five Cristeros, or rebels with arms inside. When they were stopped they hopped out of the vehicle and began shooting at the soldiers who halted them hurting them badly. ${ }^{108}$ However three other soldiers who were also on duty were able to return fire killing three of the Cristeros in the car where one got away and

${ }^{104}$ NAUS, DOS, 59, M1370, Internal Affairs of Mexico 1930-1939, 12,812.00/DURANGO/191, E.W. Eaton American Vice Consul in Durango, March 1936.

${ }^{105}$ Ibid.

${ }^{106}$ Ibid.

107 Ibid.

${ }^{108}$ Ibid. 
one was caught later in the park. ${ }^{109}$ A Cristero leader was killed due to this brawl. Fighting between rebels and federal troops not only happened in the city and mountains but in random places like a vehicle.

Even though leaders were located and linked there remained many groups and many leaders to keep the movement going.

The Mexican military had attempted to contain the attacks by the Cristero rebel groups in the state of Durango with little success despite the fact that the federal troops had much more weapons and ammunition in comparison with the new Cristeros. It was stated that, "The number of bandits, or Cristeros, in this state have increased in numbers and in activities during the month. Three contacts with Federal troops were reported during which several Cristeros, as well as soldiers, including a Captain, were killed."110

A letter argued that, the situation with rebels, violence, and schools had reached a point where action was needed to stop rebels from attacking secular teachers and schools. ${ }^{111}$ These bands needed to be handled according to General Castro. ${ }^{112}$

Federal troops were responsible for locating the Cristero rebels in the state of Durango. The Mexican military did however have difficulty in locating these particular groups of bandits within Durango due to the terrain and

\footnotetext{
109 Ibid.

${ }^{110}$ NAUS, DOS, 59, M1370, Internal Affairs of Mexico 1930-1939, 12,812.00/DURANGO/247, Political Report, November 1937.

${ }^{111}$ Ibid.

${ }^{112}$ Ibid.
} 
geography of the state, which was rural and mountainous especially in Southern Durango and the areas like Soledad.

For example, one letter explained, "As soon as the military headquarter learned of this attack the three army planes as well as troops from the $12^{\text {th }}$ and $40^{\text {th }}$ Battalions, and the $29^{\text {th }}$ regiment stationed here were ordered to Soledad to locate this band. In as much as it is reported that these Cristeros went into the mountains to the west of Soledad these troops have been unable to locate them up to the present time."113 The mountains proved to be a safe haven for rebels.

Meanwhile, the non - violent reactions mounted as well. The school became an avenue for a political power struggle between two pro - Mexican groups. ${ }^{114} \mathrm{~A}$ strike of secular schoolteachers happened because the governor decided not to shut down rural clandestine schools, which had been shut down in most areas of the state of Durango. ${ }^{115}$

Also, secular schoolteachers appealed for protection to the leader of the $10^{\text {th }}$ military zone. Male teachers from the district along the DurangoTepehuanes railway, from the northern and from the southeastern parts of Durango have been forced to abandon their schools, called upon General Castro en masse on May 20, asking him for protection from the different bands of rebels and Cristeros operating in those parts of the state. ${ }^{116}$ Secular teachers were

\footnotetext{
${ }^{113}$ Ibid.

${ }^{114}$ Ibid.

115 Ibid.

${ }^{116}$ Ibid.
} 
given arms and ammunition as well as being informed how to organize agrarian people to come to their aide if there is an attack on them. ${ }^{117}$

How was the interaction between state government and education institutions in the state? It is these intense steps displayed here that caused peasants hurt and resorting to violence. The sources give us detailed information for $5 \%$ of parishes, allowing us to see a backed up trend.

In a municipal district also named Durango the municipal president gave orders to arrest and charge a fine to any parents of kids who were currently not enrolled in public schools in the town of Otinapa. ${ }^{118}$ In Canatlán, the state government closed a private town school. ${ }^{119}$ It had been run as clandestine school. ${ }^{120}$ In both towns the closures put priests not only out of a job of preaching and taking care of peoples souls and teaching. ${ }^{121}$

In contrast the Durango state government did not arrest and fine the parents of children attending secular schools. The attacks mentioned above could only be interpreted as a deliberate attack against folk Catholic ways of life. Even though the situation was somewhat ameliorated by Mexico City's decision

\footnotetext{
${ }_{117}^{11}$ NAUS, DOS, 59, M1370, Internal Affairs of Mexico 1930-1939, 12,812.00/DURANGO/191, E.W. Eaton American Vice Consul in Durango, March 1936.

${ }^{118}$ NAUS, DOS, 59, M1370, Internal Affairs of Mexico 1930-1939, 12,812.00/DURANGO/191, Political Report, March 1936.

119 Ibid.

120 Ibid.

${ }^{121}$ These closures caused much anger and frustration by the folk Catholic population in both states. This tension was seen throughout the primary and secondary education realm.
} 
to reopen a small amount of churches ${ }^{122}$ and indirectly also some school facilities.

Many private Catholic schools which operated in the homes of priests were discovered by the government leaders exposed to be violating the orders and were closed by Federal School Inspectors. For example, it was stated that, "The local Federal School inspector ordered three schools found in private homes to be closed. According to the local press, the Federal School Inspector denounced some of the teachers in these schools as nuns but this accusation was denied by the Archbishop in a personal interview. The action of the Federal School Inspector had undoubtedly caused the suspension of classes in most schools which have been operated in private homes."123

These closings only added further strains to the already splintered relationship between the Catholic Church and the state in the 1930s in Durango. For example, in the same report it was stated that, "On September 24, 1937, the state legislature passed a law to the effect that all education supported by the State of Durango is to be socialistic to the extent of excluding the teaching of all religious doctrines, and that no private school can function with out first having obtained authorization from the appropriate officials." ${ }^{124}$ Passage of this law was

\footnotetext{
${ }^{122}$ The sources list 3000 church openings, but did not detail how many were opened in the state of Durango alone. There were approximately sixty priests in the state in October 1934.

${ }^{123}$ NAUS, DOS, 59, M1370, Internal Affairs of Mexico 1930-1939, 12,812.00/DURANGO/191, Political Report, March 1936.

${ }^{124}$ Ibid.
} 
met with infuriation from the Catholic community in Durango and Old Cristeros were in the midst of a new phase of the Cristero war.

The political situation overlapped with the religious situation in the many ways. First, the introduction of new government leaders who threatened to set further limitations of the number of priests were operating in the state. Second, the teetering relationship between these governmental state leaders and the religious leaders of the state of Durango occurred. These priests acted as the teachers to most of the students in private religious schools throughout the state of Durango.

The Catholic community in Durango met demonstrators in favor of secular education with particular backlash. For example, it was stated that, "The patriotic demonstrations during September 16 were held without disorder. The parade this year was composed principally of school children, a number of whom were organized into drum and bugle corps, and in uniforms of various styles. Many of the units of children carried sickles, hammers, picks, shovels and other tools of labor, with a small number of troops bringing up the rear."125 This type of outward and public demonstration would have only added fuel to the already burning fire that the Old Cristeros felt toward the federal government and those who denounced the Catholic education.

\footnotetext{
${ }^{125}$ NAUS, DOS, 59, M1370, Internal Affairs of Mexico 1930-1939, 12,812.00/DURANGO/261, Political Report, September 1938.
} 
While the folk Catholic population adhered to older celebrations that upheld the saints such as la Virgin de Guadalupe, the revolutionary secular population celebrated Mexican Independence Day and other nationalistic symbols.

The onslaught of the restrictions placed on religious education within the state of Durango gave rise to a new phase of the Cristero war that was aimed at putting an end to secular education. For example, the political report from October, 1934 stated that, "The surrender of these groups of rebels apparently brings to a close the rebel or Cristero activities in this state which began during the month of October, 1934, and which began during the month of October, 1934, and which has cost both the Federal troops and his rebels numerous lives, apart from the destruction of property and the financial losses suffered by innocent persons." ${ }^{126}$ Although the Cristero rebellion was said to have been over in 1934, there were still rebellious activities and violent attacks taking place. These attacks targeted the secular teachers in the state of Durango after 1934.

The result was that parties on both side were killed although the Cristeros often lost more men than the federal troops, there were countless numbers of Cristeros that were in essence undetected due to the geographic nature of the state of Durango.

${ }^{126}$ Ibid. 


\section{Chapter 3: Jalisco}

The Mexican state of Jalisco is located in the northwest of the country bordering the states of Nayarit, Zacatecas, Aguascalientes, San Luis Potosi, Guanajuato, Colima, Michoacán, and Durango. The state has 213 miles of coastline on the Pacific Ocean to the west. It is made up of a diverse terrain that has forests, beaches, lakes, and plains. Jalisco lies between the tropical south and the temperate north. The Santiago and Lerma rivers connect with Lake Chapala, the largest fresh water lake in Mexico. It has a large capital city of Guadalajara.

President Plutarco Calles had entrusted the political control of the state first to Sebastián Allende in 1932 and then to Everardo Topete in 1935. Both had been eager to advance secular education against Catholic resistance. ${ }^{127}$ Initially, under Governor Allende, Licenciado Ignacio Jacobo had been the lead administrator of state education. Initially both men let traditional educational practices stand. But, toward the end of Jacobo's tenure, Calles demanded the intensification of educational reform. Soon thereafter, he replaced Jacobo with Alberto Teran. This was a clear message from Mexico City that the revolutionary leadership would no longer tolerate accommodations of educational practices in this conservative state. Calles' policy intensification created the clashes that will be examined on the following pages.

${ }^{127}$ NAUS, DOS, 59, M1370, Internal Affairs of Mexico 1930-1939, 13,812.00/JALISCO/150. 
First, Jalisco's case needs to be researched for its own sake. However, second, studying Jalisco will allow us to compare the rural experience of Durango with rural and urban experience of Jalisco. Jalisco lets us add a second stage for comparison: the urban environment of Guadalajara. This urban environment is divided into primary-secondary education and a new higher education level, something that Durango does not possess.

Jalisco's urban higher education sector consisted originally of the University of Guadalajara. As Mexico City's educational reform was forced upon the state the University of Guadalajara's membership split and introduced the battle over education into this environment. One result was the creation of a new university called The Autonomous University of the West. These universities, too, became a stage where the argument between proponents of secular and traditional education was struggled over. Thus, looking at Jalisco is not just a repetition of Durango's story: it adds knowledge about a new state, a rural urban divide, and a look at the differences between Mexico City and one region's center.

For this state we have some numbers that help us gain an understanding of the primary and secondary educational sector. In state primary schools average enrollment was 70,321 students during 1936-1937. ${ }^{128}$ But only 45,752 pupils attended. ${ }^{129}$ Most likely a large number of them stayed at home in order to

\footnotetext{
${ }^{128}$ NAUS, DOS, 59, M1370, Internal Affairs of Mexico 1930-1939, 13,812.00/JALISCO/204, Report, February 1938.

${ }^{129}$ Ibid.
} 
help their parents with agricultural work. Their absence was not an act of voting with their feet against the state educational policy. Still, most likely a noteworthy number of parents withheld their children also because they disagreed with state educational program.

In addition, as we will explain later, there existed many private and clandestine schools. The total number of secular, private, and clandestine schools was estimated to be $538 .^{130}$

Otherwise the same national political macro - context applies as described in the Durango chapter. ${ }^{131}$

\section{Jalisco's Culture of Violence: Rebel Side}

In a similar form to Durango, there existed two sides of a regional culture of violence in Jalisco. There was a battle between federal troops and antigovernment gangs. In the rural regions of Jalisco the situation had similarities with the rural state of Durango. However, when it came to the urban areas of Jalisco there were real differences, which will be illuminated later. First the rebel side will be examined.

Bandit activities were located in the rural Los Altos region of the state. They were referring to themselves as Cristeros. ${ }^{132}$ The Los Altos region was the main theater for the violence that occurred in the state; however, smaller bands

\footnotetext{
${ }^{130}$ NAUS, DOS, 59, M1370, Internal Affairs of Mexico 1930-1939, 13,812.00/JALISCO/204, Report, February 1938. The sources do not provide data that allow further differentiation between those three school forms.

131 See page 14-16.

132 U.S. Military Intelligence Reports: Mexico 1919-1941, Reel 2, G-2 report 3187- 3020- d, Robert E. Cummings, Captain, Infantry, DOL, Acting Military Attaché, December 29, 1930.
} 
existed in other areas of the state. Due to the geographic topography of the region it was challenging for federal troops to monitor rebel groups actual numbers and pinpoint locations in the mountains.

Areas of gang activity also included Zacatecas, Northern Jalisco, and Southern Durango. ${ }^{133}$ In these areas and others the main problem remained to be the implementation of secular or Mexico City style education in a highly Catholic and rural area.

Similar to the situation in Durango, the rural nature of northern Jalisco made it difficult for federal troops to know exact rebel numbers and locations. There were also many armed bandits in the Sayula and Ciudad Guzmán regions who were fully operational during this period despite many reports that things had begun to settle down there. ${ }^{134}$

Many gang members had previously served as Cristero leaders, like Lauro Rocha, who was once the leader of a band of Cristeros in the Los Altos region and continued to lead his rebel faction after the formal ending of the rebellion. ${ }^{135}$

Similar to Lauro Rocha, General Degallado had fought on the side of the Cristeros in the 1920's and continued fighting in the 1930s. The successor to

\footnotetext{
${ }^{133}$ NAUS, DOS, 59, M1370, Internal Affairs of Mexico 1930-1939, 13,812.00/JALISCO/172. Political Report by George H. Winters, March 1936.

${ }^{134}$ NAUS, DOS, 59, M1370, Internal Affairs of Mexico 1930-1939, 13,812.00/JALISCO/152.

${ }^{135}$ NAUS, DOS, 59, M1370, Internal Affairs of Mexico 1930-1939, 13,812.00/JALISCO/188.
} 
General Goroteista, General Degallado had served as chief of the Cristeros and divided groups of bandits into small cohorts. ${ }^{136}$

Priests were being arrested for their involvement in assaults on secular school - teachers. ${ }^{137}$ Priests had been involved in the Cristero gang in Durango as well.

One question is how many fighters existed? The sources tell us, “...there are probably several thousand armed men in the Los Altos region." ${ }^{138}$ It was articulated that, "Although there were several reports of rebels subdued by the military, their activities are believed to have accomplished little."139 Nevertheless, it remains impossible to pinpoint a definite number of rebels as groups grew and shrunk, regrouped, and also hid in mountain areas where no government observer was able to count them in a precise way. ${ }^{140}$

We have specific information for Sayula. There lived 100 rebels. ${ }^{141}$ Sayula was located 62 miles south of the central city Guadalajara in a rural area. Similar to Durango, rebels were broken down into local gangs.

Many of the main actors in the violence against secular education had participated in the Cristero rebellion of the 1920s and already held weapons or had procurement links made. Cristeros, like leader Lauro Rocha, used mostly women to secure arms and ammunition in Mexico City for the rebel cause in the

\footnotetext{
${ }^{136}$ U.S. Military Intelligence Reports: Mexico 1919-1941, Reel 2, G-2 report no. 2424- 3020-d, Gordon Johnson, Lieutenant - Colonel Cavalry Military Attaché, June 21, 1929.

${ }^{137}$ NAUS, DOS, 59, M1370, Internal Affairs of Mexico 1930-1939, 13,812.00/JALISCO/172. Political Report by George H. Winters, March 1936.

${ }^{138}$ Ibid.

139 Ibid.

${ }^{140}$ Ibid.

${ }^{141}$ NAUS, DOS, 59, M1370, Internal Affairs of Mexico 1930-1939, 13,812.00/JALISCO/189.
} 
Los Altos region. ${ }^{142}$ Rebel women in Jalisco played a far greater role than in Durango. Women carried weapons and ammunition from agents they knew in Mexico City. There was a link to Mexico City for arms procurement, which was absent in Durango. Cristeros remained active and well equipped with Thompson machine guns of U.S. manufacture, which they procured from Mexico City. ${ }^{143}$

Firecrackers were used as well as explosives. A priest placed a large firecracker in the window of a secular schoolteacher, which shattered some glass in Ahualulco. ${ }^{144}$ Priests would have had firecrackers in their possession because of their use in festivals and celebrations.

During fights with federal troops, Cristeros were able to procure some arms. Federal troops lost only 162 arms for the years $1928-1929 .{ }^{145}$ Federal troops lost less men, arms, and provisions and had more to begin with than the rebels. The rebels in Sayula were well armed and supplied with ammunition from the government plant in District Federal. ${ }^{146}$

Next we ask what forms of attacks took place? The rural culture of Jalisco represented folk Catholicism and a deeply syncretized indigenous and European traditions or mestizo culture. ${ }^{147}$ The symbol of the rebel side was the Virgin de Guadalupe who herself represented mestizo culture. A riot ensued between

\footnotetext{
${ }^{142}$ NAUS, DOS, 59, M1370, Internal Affairs of Mexico 1930-1939, 13,812.00/JALISCO/186. Political Report by George H. Winters.

${ }^{143}$ NAUS, DOS, 59, M1370, Internal Affairs of Mexico 1930-1939, 13,812.00/JALISCO/163. 144 NAUS, DOS, 59, M1370, Internal Affairs of Mexico 1930-1939, 13,812.00/JALISCO/160. ${ }_{145}$ U.S. Military Intelligence Reports: Mexico 1919-1941, Reel 2, G-2 report 3034- 3020- d, Report, August 8, 1930.

${ }^{146}$ NAUS, DOS, 59, M1370, Internal Affairs of Mexico 1930-1939, 13,812.00/JALISCO/189.

${ }^{147}$ British National Archives Kew Gardens, Mexican Religious Activities of the 1930s, FO544, Annual Report, 1931.
} 
labor organization called 'Casa Amiga del Obrero' and a Church community during a procession in Guadalajara in honor of the Virgin de Guadalupe. ${ }^{148}$ The rural indigenous Catholics had the power to "split the country right down the middle." 149

In 1931 a riot happened due to the anti- clerical laws. This was possibly the start of a new phase of the Cristero Rebellion in Jalisco, if the government pursued anti - clericalism. ${ }^{150}$ The government in 1931 had seriously started to pursue gangs who appeared in Jalisco. ${ }^{151}$

In response to riots against the church, the fanatical religious group called 'Liga Religiousa de Mexico' tried, without success, to start an armed rebellion. ${ }^{152}$

Priests were an integral part of the rebel cause. They represented a crosssocial alliance, which included every parishioner and invited them to be on the same level with the religious leaders. Priests were being arrested for their involvement in assaults on secular school - teachers. ${ }^{153}$

There were six occurrences mentioned in the sources describing attacks on secular school - teachers, with two of these indicating multiple victims in Jalisco following the Cristero Rebellion. ${ }^{154}$ The murder of a public school teacher

\footnotetext{
148 Ibid.

149 Ibid.

150 Ibid.

151 lbid.

152 Ibid.

${ }^{153}$ NAUS, DOS, 59, M1370, Internal Affairs of Mexico 1930-1939, 13,812.00/JALISCO/172.

Political Report by George H. Winters, March 1936.

${ }^{154}$ Unfortunately the sources seldom provide specific names of people attacked.
} 
at the hands of the rebels was reported in April of $1937 .{ }^{155}$ The gender of this teacher was not stated and the location was not mentioned. A group of secular school - teachers had been assaulted by a band of rebels in San Martin Hidalgo, 40 miles west of Guadalajara. ${ }^{156}$

Many of these secular school - teachers were killed in the area by these gangs because they posed a threat to the folk Catholic life and they disagreed with the fundamentals of Revolutionary state - led, secular education. ${ }^{157}$

To say it differently, in the 1920s phase of rebellion secular politicians had been the target of assaults. Now, even with blessing of the priests, secular teachers became targets of attack.

A public school teacher was attacked by a band of rebels near Cinco Minas where she died from her wounds in February of $1937 .{ }^{158}$ More often than not female secular school teachers did not survive these attacks, while in other examples their male counterparts are able to escape brutally beaten and bloodied but alive.

Secular schoolteachers and agrarians were attacked by gangs like in Durango. These incidences highlight the fact that the Cristero Rebellion severely impeded public, primary, and secondary education because of the violence against teachers of secular or anti- clerical education. However, these attacks

\footnotetext{
${ }^{155}$ NAUS, DOS, 59, M1370, Internal Affairs of Mexico 1930-1939, 13,812.00/JALISCO/192.

${ }^{156}$ U.S. Military Intelligence Reports: Mexico 1919-1941, Reel 2, G-2 report 3187- 3020- d, Robert E. Cummings, Captain, Infantry, DOL, Acting Military Attaché, December 29, 1930.

${ }^{157}$ NAUS, DOS, 59, M1370, Internal Affairs of Mexico 1930-1939, 13,812.00/JALISCO/151.

${ }^{158}$ Ibid., 13,812.00/JALISCO/189.
} 
were brought on by the legal restrictions placed on Catholics and the Catholic private education system.

In October of 1936, the newspaper entitled EL JALISCIENCE "reported the usual number of alleged atrocities committed by rebels against agrarians and Socialistic school teachers." ${ }^{159}$ The newspaper referred to these attacks as common. Both agrarians and secular school - teachers were attacked in Jalisco.

As in Durango, when it came to education and religion, the teaching of religion was prohibited in public as well as in private, clandestine schools. ${ }^{160}$ And yet, priests and bishops continued to teach secretly in privately owned homes. ${ }^{161}$ Also in this state the most extreme government measures were not enacted. Priests continued to practice in a reduced number of parishes. They also continued to look for avenues to teach.

The Mexican folk Catholic Church used private homes as schools and churches when the state closed the doors on their buildings. It was stated that:

While parochial schools are still closed instruction is being given to small classes of ten by their formers teachers in private homes. Likewise the seminary candidates are receiving instruction in private, many of them in preparation for entrance in the Moctezuma Seminary, near Las Vegas, New Mexico, established by American Jesuits for the education of Mexican priests. ${ }^{162}$

These Catholic men and women had to adapt to the changes.

\footnotetext{
${ }^{159}$ NAUS, DOS, 59, M1370, Internal Affairs of Mexico 1930-1939, 13,812.00/JALISCO/182. Political Report by George H. Winters.

${ }^{160}$ NAUS, DOS, 59, M1370, Internal Affairs of Mexico 1930-1939, 13,812.00/JALISCO/163.

161 Ibid.

162 NAUS, DOS, 59, M1370, Internal Affairs of Mexico 1930-1939, 13,812.00/JALISCO/219, George H. Winters, American Consul, Mexico, January 1939.
} 
The Archbishop of Jalisco, Francisco Orozco y Jimenez replaced the previous Archbishop named Jose Garibi Rivera in February of $1936 .{ }^{163}$ Orozco y Jimenez was chosen because the Catholic Church thought he would bring alleviation to the current difficulties between church and state. ${ }^{164}$ It was stated that the Archbishop of Jalisco articulated a robust dislike for secular education due to the extremism taught by the state. ${ }^{165} \mathrm{He}$ claimed that the children from the rural regions of the state lack of attendance in public schools was due to the Church's disapproval of the education provided by the state. ${ }^{166}$ The church's opposition to the secular schooling that was supported by the state government would prove to be a dividing issue on the regional level.

The elements of mestizaje or the cultural mixing between indigenous and Spanish religious, practices, and norms had been ingrained in the people of Jalisco since as far back as they could remember. It would not be easy to change this in a short time and much backlash and upheaval would result in such a push by the heads of the state and the President in Mexico City.

While the governor closed Catholic schools, secular schools remained open. However secular schools maintained extremely low enrollment numbers due to Catholics reluctance to enroll their children in Revolutionary state - led schools. The closing of Catholic sponsored schools mirrored the closing of many

\footnotetext{
${ }^{163}$ NAUS, DOS, 59, M1370, Internal Affairs of Mexico 1930-1939, 13,812.00/JALISCO/171. Political Report written by George H. Winters, February 1936.

${ }^{164}$ Ibid.

${ }^{165}$ NAUS, DOS, 59, M1370, Internal Affairs of Mexico 1930-1939, 13,812.00/JALISCO/172.

Political Report by George H. Winters, March 1936.

${ }^{166}$ Ibid.
} 
churches throughout the state as well as restrictions decreed by President Plutarco Elias Calles on the number of priests allowed in each state that had sparked the Cristero rebellion. In some cases the number of Catholic schools was cut in half, which led to the use of private homes as meeting places and schools during this period.

For example, in June of 1936, a Catholic school was closed by the state and two others were being closed as well. ${ }^{167}$ The church saw these closures of schools as a direct threat to religious schooling because it meant secular schooling would become popular and the Catholic Church would lose control over educating the youth of Mexico, more specifically the state of Jalisco.

The relationship between the Catholic Church and the government remained push and pull. It was claimed that, "Although petitions for the re opening of other churches have not yet been granted, it is rumored that an offer has been made to the church where by other churches will be opened if Catholic families will agree to send their children to public schools." ${ }^{\text {168 }}$ This appeared to be an attempt to manipulate the Catholic community to send their children to public school.

At the same time many restrictions on church numbers in the area had not been enforced as much as in previous years. ${ }^{169}$ In October 1937 several church sponsored primary and secondary schools reopened in the area, but "while

\footnotetext{
${ }^{167}$ NAUS, DOS, 59, M1370, Internal Affairs of Mexico 1930-1939, 13,812.00/JALISCO/177. Political Report by Norris S. Haselton, American Vice Consul, June 1936.

${ }^{168}$ NAUS, DOS, 59, M1370, Internal Affairs of Mexico 1930-1939, 13,812.00/JALISCO/198.

${ }^{169}$ NAUS, DOS, 59, M1370, Internal Affairs of Mexico 1930-1939, 13,812.00/JALISCO/199.
} 
nominally non- religious it is commonly known that they are supported by the Church. The state authorities in general were lenient in the enforcement of the religious laws." ${ }^{170}$ But despite the re-opening of clandestine schools, Catholics in the area still resented the legal restrictions placed on them by the state governor and the administration in Mexico City. ${ }^{171}$ Parents in the year $1936-1937$ chose to withhold 24,569 pupils from school attendance. ${ }^{172}$ Most of them were reenrolled in private and clandestine schools. Unfortunately, the sources do not allow us to know how many of them existed. A combined total number of schools was know when combining clandestine, private, and secular public schools. That number was $538 .^{173}$

Although they were not formally enrolled in a secular school, these Catholic children received education in the private sphere where they experienced a folk, Catholic curriculum.

Education became the vein of control held by the politicians in Jalisco like governor Everardo Topete. Topete, through political bossism was able to oversee what the children and adults were learning and therefore, whoever was in control of the state politically could decide what schools would remain open and what schools would remain closed and unfunded.

\footnotetext{
170 Ibid.

${ }^{171}$ Ibid.

172 NAUS, DOS, 59, M1370, Internal Affairs of Mexico 1930-1939, 13,812.00/JALISCO/204, Report, February 1938.

${ }^{173}$ Ibid.
} 
There were five possible outcomes of attack for rebel gangs and their members: death, surrender, prisoner, and retreat or regroup. In 1928 2,365 Cristeros were killed. ${ }^{174}$ The next year 870 Cristeros died. ${ }^{175} 3,235$ Cristeros were killed by Federal troops in both years combined. ${ }^{176}$ An older Cristero leader from the neighboring state, Colima, was killed. ${ }^{177}$ Despite the fact that the sources only allow for knowledge from these two years, the data still provides meaningful information based on outcomes.

Many of the same themes introduced in Durango became clearly visible in Jalisco. The role of surrender as an option within the culture of violence was impressive. Large numbers of gangs and their leaders had surrendered in Jalisco. 27 men surrendered with priest Zerron Arrias. ${ }^{178} 62$ men surrendered with Emiliano Hernandez. ${ }^{179} 104$ men surrendered with Angel Ortiz Cuatezon and Luis Martinez. ${ }^{180} 12$ men surrendered with priest Luis Ordonez. ${ }^{181} 215$ men surrendered with Bernardino Tapia. ${ }^{182} 92$ men surrendered with Vicente Diaz and

\footnotetext{
${ }^{174}$ Ibid.

${ }^{175}$ NAUS, DOS, 59, M1370, Internal Affairs of Mexico 1930-1939, 13,812.00/JALISCO/182. Political Report by George H. Winters.

176 lbid.

177 U.S. Military Intelligence Reports: Mexico 1919-1941, Reel 2, G-2 report 3034- 3020- d, Report, August 8, 1930.

${ }_{178}$ U.S. Military Intelligence Reports: Mexico 1919-1941, Reel 2, G-2 report no. 2424- 3020-d, Gordon Johnson, Lieutenant - Colonel Cavalry Military Attaché, June 21, 1929.

${ }^{179}$ Ibid.

${ }^{180}$ Ibid.

181 Ibid.

182 Ibid.
} 
Abundio Villalobos. ${ }^{183} 272$ men surrendered with Manual Fernandez and Fernando Lara Diaz. ${ }^{184}$

Two priests were leading a group of bandits who had surrendered. This made Jalisco unique in comparison to Durango. In Durango, priests fought against the government and secular education in non - violent forms like opening clandestine schools. In Jalisco, priests were leading into battle decent sized groups of rebels against federal troops.

Many rebel leaders surrendered. ${ }^{185} 259$ Cristeros surrendered in $1928 .{ }^{186}$ In 1929, Federal troops obtained 1,351 surrendered rebels. ${ }^{187}$ Regardless of the fact that data was given specifically for the years of 1928 and 1929 this information is extremely useful when trying to identify patterns.

Although less common, prisoners of war did exist on the Cristero side. In 1929 Federal troops obtained 110 Cristeros as prisoners. ${ }^{188}$ These 110 prisoners were the only ones reported by U.S. military intelligence. There could possibly have been more prisoners that went unreported.

\footnotetext{
183 Ibid.

184 Ibid.

${ }^{185}$ U.S. Military Intelligence Reports: Mexico 1919-1941, Reel 2, G-2 report no. 2424- 3020-d, Gordon Johnson, Lieutenant - Colonel Cavalry Military Attaché, June 21, 1929.

${ }^{186}$ U.S. Military Intelligence Reports: Mexico 1919-1941, Reel 2, G-2 report 3034- 3020- d, Report, August 8, 1930.

${ }^{187}$ Ibid.

${ }^{188}$ U.S. Military Intelligence Reports: Mexico 1919-1941, Reel 2, G-2 report 3034- 3020- d, Report, August 8, 1930.
} 
There were still some Cristeros that remained free in the field. ${ }^{189}$ Those regrouped and formed new gangs to live and hide in mountain caves until they were ready to descend from the mountainous area once again.

\section{Culture of Violence: Government Side}

In similar form to the Cristero side, the government also had its own culture of violence. It consisted of similar themes, however the sources allow considerably less information.

The government side was made up of federal troops, generals, political figures, agrarians given land by the government, and anyone who was in favor of secular education or against the Catholic Church. Unlike the Cristero side, the government side was less cohesive.

The military had much better access to weapons than the Cristero gangs. In addition to government supplied guns, ammunition, and explosives, federal troops gained some arms after fighting with gangs.

In 1928 Federal troops obtained 2,745 horses, 87 mules, 213 Mausers, 2013030 pistols, 162 pistols, and 679 various arms from the Cristeros. ${ }^{190}$ The following year federal troops obtained 1,361 horses, 40 mules, 125 Mausers, 124 3030's, 63 pistols, and 1,000 various arms from Cristeros. ${ }^{191}$

\footnotetext{
${ }^{189}$ Ibid.

190 U.S. Military Intelligence Reports: Mexico 1919-1941, Reel 2, G-2 report 3034- 3020- d, Report, August 8, 1930.

${ }^{191}$ lbid.
} 
In Lagos de Moreno two pro-secular people were arrested because they were caught in the act of attempting to bomb a church with dynamite. ${ }^{192}$ Dynamite was used far less in Jalisco in comparison to Durango.

Violent acts were committed against the Catholic community as well as representatives of that community. Buildings were also included as targets of this aggression. Violent threats were also common.

Catholic priests lives have been threatened by local agrarians in Jalisco who were claiming war on the church. ${ }^{193}$ The relationship between folk culture and state sponsored agrarians in Jalisco was reverse to that in Durango. In Jalisco agrarians do not need government nudging to start fighting they initiate it themselves.

Death threats were common during this time period against representatives of the Catholic Church and the rebellion. Extreme anti clericalists were threatening the life of Archbishop of Guadalajara, Jose Garibi Rivera, in Jalisco. ${ }^{194}$ Although Rivera was unscathed by the incident, the threat of death was real and serious.

\footnotetext{
192 U.S. Military Intelligence Reports: Mexico 1919-1941, Reel 2, G-2 report 3187- 3020- d, Robert E. Cummings, Captain, Infantry, DOL, Acting Military Attaché, December 29, 1930.

${ }^{193}$ U.S. Military Intelligence Reports: Mexico 1919-1941, Reel 2, G-2 report 3187- 3020- d, Robert E. Cummings, Captain, Infantry, DOL, Acting Military Attaché, December 29, 1930.

${ }^{194}$ British National Archives, Mexican Religious Activities of the 1930s, FO572, Annual Report, 1932.
} 
This volatile situation caused many problems for education in the area. For example, in the neighboring state of Colima ${ }^{195}$ there was a burning of a rural school. ${ }^{196}$ The public showing of protest against traditional Catholic education provoked violence against secular teachers and buildings.

The government did however try to stop these attacks by sending military generals into the heavy bandit areas to put down the aggressors and re-establish order from Mexico City and the Callista faction governor. General Antonio Rios Zertuche had been confronting the bandit groups in the area. ${ }^{197}$ General Geurrero was sent to Los Altos region to restore order. ${ }^{198}$

Religious buildings were frequently stolen from Catholics by the government. ${ }^{199}$ Then buildings were covered with nationalistic symbols like the secular Mexican national flag. ${ }^{200}$ The painting of the flag was a symbol of the revolution and the state just as the Virgin de Guadalupe was the symbol of the rebel side. This was a common practice in Mexico City and that was being mimicked in Jalisco. The government also prohibited baptisms and marriages. ${ }^{201}$

Beginning in 1934 the relationship between church and state in Jalisco became, once again, more unstable. Once Minister of Education Sr. Narsciso Bassols pushed secularized education and the introduction of sexual education,

\footnotetext{
${ }^{195}$ Colima is the neighboring state of Jalisco. It is a small state that appears to be inside of the larger state of Jalisco. It shares a small border with Michoacán but the entire state of Colima besides that small border is neighboring Jalisco. Many bandits and rebels resided there as well. ${ }^{196}$ NAUS, DOS, 59, M1370, Internal Affairs of Mexico 1930-1939, 13,812.00/JALISCO/198. ${ }^{197}$ NAUS, DOS, 59, M1370, Internal Affairs of Mexico 1930-1939, 13,812.00/JALISCO/197. ${ }^{198}$ NAUS, DOS, 59, M1370, Internal Affairs of Mexico 1930-1939, 13,812.00/JALISCO/163.

199 Ibid.

${ }^{200}$ Ibid.

${ }^{201}$ lbid.
} 
the government experienced an even more extreme backlash from the folk Catholic community in Jalisco. ${ }^{202}$

Introduction of sexual education meant a direct attack against the folk Catholic Church, its community, and Jalisco's educational practices. This regional backlash differed from its more open reception in Mexico City and other urban areas.

In Jalisco the federal government personally intervened in a way not seen in Durango. President Plutarco Calles himself made a decision to travel into rebel territory and deliver a personal verbal assault against Jalisco's traditional practices. In 1934 he traveled to Guadalajara to give a fiery speech. In it he described the nature of the ongoing struggle and its many avenues. A British observer reported the content of his speech. Among other things he exclaimed:

Anyone who had the interests of the revolution at heart to rescue the youth of the country from the clutches of clericalism and conservatism [...would see...] that clergy had no further hand in educating the youth of Mexico.

The children of the country belonged to the revolution and not to the Church and he summoned all governments of all the states of the republic and all true representatives of the revolution to drive out the enemies of the country from the trench into which they had dug themselves in. ${ }^{203}$

Calles journey to Guadalajara and speech was an outsider's call to action against traditional folk Catholic education. It exhibited the perceived enslavement of the youth of Mexico by the Church and cried out the message of the revolution.

\footnotetext{
202 Ibid.

${ }^{203}$ British National Archives, Mexican Religious Activities of the 1930s, FO371, 18170, Reel 74, Annual Report, 1934.
} 
Although it was non- violent in nature, these words stabbed the Catholic Church and believers using words as the blade.

Public disdain for Catholic education was common among secular educators. Strikes were taking place that were led by Mexico City style or secular educators. ${ }^{204}$ Strikes were a common form of non - violent protest against Catholic education.

Due to the lack of enrollment of children in the secular public schools in the state, in June of 1937 , more than 100 children were taken into custody because they refused to enroll in school in order to convince the children's parents to enroll them; they were released promptly. ${ }^{205}$ The government realized that they could not force these parents to enroll their children into a state run secular school. The laws against the church were becoming less pronounced within the state of Jalisco. Despite the appearance of leniency, the state still took custody of Mexican children away from their entire families which was a tremendous issue for these families and caused them anger and pain. ${ }^{206}$

The government side experienced only one outcome of attack, death. They were not likely to retreat because they always outnumbered rebel gangs. None were reported as being taken prisoner by rebels either.

\footnotetext{
${ }^{204}$ NAUS, DOS, 59, M1370, Internal Affairs of Mexico 1930-1939, 13,812.00/JALISCO/163.

${ }^{205}$ NAUS, DOS, 59, M1370, Internal Affairs of Mexico 1930-1939, 13,812.00/JALISCO/198.

${ }^{206}$ Ibid.
} 
The total number of Federal troops killed by Cristeros between 1928 and 1929 was $406 .{ }^{207}$ Although this number was small in comparison to the larger number of rebels that were killed it is still a considerable amount of loss.

\section{E. Higher Education}

A new aspect of the culture of violence was the opening of a new exclusive stage in the urban center of Guadalajara. Here events at the University of Guadalajara added an additional stage for struggles over higher education to the humble adobe buildings of first and secondary education in the countryside.

We have to begin by narrating the key event so that the reader can understand the deeper struggles.

Before 1934 there existed only one university in the capital city of Jalisco: the University of Guadalajara. ${ }^{208}$ Then, in March 1934 the higher education sector experienced the division of higher education in this city. ${ }^{209}$ Suddenly, private citizens and professionals pooled funds to finance a new university called Autonomous University of the West. ${ }^{210}$ After one year of planning and preparation, in May 1935 students could chose between enrolling in one university financed by the revolutionary government of Mexico City or a rival financed by anti-revolutionary groups of Jalisco. ${ }^{211}$ Not surprisingly the battles over the content of education also appeared in these higher education

\footnotetext{
${ }^{207}$ NAUS, DOS, 59, M1370, Internal Affairs of Mexico 1930-1939, 13,812.00/JALISCO/182. Political Report by George H. Winters.

208 NAUS, DOS, 59, M1370, Internal Affairs of Mexico 1930-1939, 13,812.00/JALISCO/194. 209 Ibid.

210 NAUS, DOS, 59, M1370, Internal Affairs of Mexico 1930-1939, 13,812.00/JALISCO/195. 211 Ibid.
} 
institutions. ${ }^{212}$ There emerged further complexities but they will be described later. First, a description of the newly founded university is appropriate.

One can argue that urban folk Catholics founded the Autonomous University. Jalisco's governor Florencio Topete thought the Church was sponsoring it. ${ }^{213}$

Fifty percent of the University of Guadalajara's student body decided to switch allegiance. ${ }^{214}$ As important was that half the faculty left as well. Second the definition of what constituted a professor also changed. Businessmen of the city volunteered to teach, often without pay. ${ }^{215}$ It was a highly partisan but very motivated body of teachers. Their dedication was to the urban Catholic folk view but also that education was supposed to lean toward natural science and professional skill education.

Quickly the Autonomous University gained higher regard than the University of Guadalajara. It was stated that:

The Autonomous University is understood to have a much larger enrollment than that of the Higher Socialistic Education Institutions. The enrollment of the Autonomous University consists of the more serious students, while the faculty consists of principal professional men of Guadalajara who, for the most part, are serving without pay. ${ }^{216}$

${ }^{212}$ NAUS, DOS, 59, M1370, Internal Affairs of Mexico 1930-1939, 13,812.00/JALISCO/198, Report, September 1937.

${ }^{213}$ NAUS, DOS, 59, M1370, Internal Affairs of Mexico 1930-1939, 13,812.00/JALISCO/195.

${ }^{214}$ Ibid.

${ }^{215}$ Ibid.

216 lbid. 
Contemporary observers believed that the Autonomous University of Guadalajara had been founded to fight back against state led education in the University of Guadalajara. ${ }^{217}$

The truth is not entirely black or white. One insider report explained "...seeing the impossibility of freeing the state from political and what they contended was 'communistic' control, the conservative element of the city proceeded to set up an entirely independent institution of higher learning which they first called Occidental University and later the Autonomous University."218

It began to be run as an independent university in May of $1935 .{ }^{219}$ Its investors and supporters were conservative professionals, businessmen, and professors who represented their own understanding of academic liberty, in this case a pro-Catholic worldview. ${ }^{220}$

The Autonomous University offered the following departments for enrollment: College of Chemical Science (pharmacy), College of Business Administration, College of Law and Social Science, College of Engineering, College of Medicine, College of Dentistry, and a preparatory school. ${ }^{221}$ Not to be forgotten the university offered the study of the Humanities. These urban Catholics or modern Catholics still adhered to Catholic ideology but welcomed modernity. But it did object to Mexico City's revolutionary curriculum.

217 Ibid.
218 Ibid.
219 Ibid.
${ }^{220}$ Ibid.
${ }^{221}$ Ibid. 
For one year, 1938-1939, we know its specific enrollment allowing us to see the strength and attraction of this educational option: 1,000 men and 200 women enrolled during 1938-1939. ${ }^{222}$

Next let's turn to the surviving half of the University of Guadalajara. After the split, the University of Guadalajara, still under familiar secular Mexico City leadership continued to operate. The number of students enrolled during 19381939 numbered between 2500 and $3000 .^{223}$ The courses offered were, professional courses in the colleges of medicine, dentistry, law and economics, physics, and mathematics (civic engineering), chemical sciences (pharmacy), veterinary, polytechnic school for training in the mechanical trades, the courses which provide elementary academic subjects, the School of Business Administration, the Secondary School, and the Preparatory School. ${ }^{224}$

The University of Guadalajara rector Licenciado Constansio Hernandez was strongly secular. ${ }^{225} \mathrm{He}$ was "considered as being far to the left in his public sympathies, nevertheless, he is charged by the students' organizations with not adhering to the University's secular ideals, as well as using his position for unnamed political ends." ${ }^{226}$

The events of the last years were beginning to impact the quality of education, regardless of a student's opinion. One observer explained:

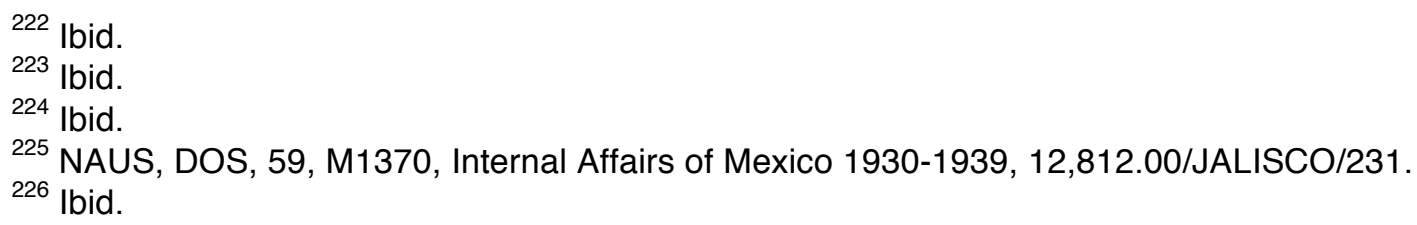


...Politics, lack of funds, and the break-down of discipline of the student body, coinciding with the progress of Mexico's program of social experimentation since 1910, have proven themselves destructive factors with resultant decline in the quality of instruction in spite of the ambitious curriculum established. There appeared to be a wide separation between the instruction prescribed and that actually available to the students. Only the college of law retains a semblance of adequacy. ${ }^{227}$

The University of Guadalajara was no longer one of the top universities in Latin America. It remained an acceptable institution to learn about science, business, medicine, and law. ${ }^{228}$ In 1939, 2,227 students enrolled. 1,758 of the students were men and 469 students were female. ${ }^{229}$

Before we can turn to the ideological struggles in these institutions it is necessary to explain the global ideological context for higher education struggles.

Globally a debate raged about the function of higher education in societies in transition. Hitler's administration was in the process of eliminating all education that did not serve the advance of National Socialism.

Moscow's communist party advanced learning if it helped communism, but it also gathered anti - fascist forces at the 1935 VII Congress of the Communist International. There the strategy of the Popular Front was imposed. Higher education only had to serve the goals Moscow's Communist Party not the choice of the individual.

\footnotetext{
${ }^{227}$ Ibid.

${ }^{228}$ Ibid. Licenciado Rabago Cornejo who served as the acting secretary for the University of Guadalajara in 1939.

${ }^{229}$ NAUS, DOS, 84, Bureau of the Interior Mexico 1930-1939, 842, Education (Institutions of Higher Learning)/File no. 810.42/136A, American Consulate M.L Stafford, May 1939.
} 
Mexico's educational leaders faced the question where their revolutionary educational goal fit into those global tensions.

Even if they would have ignored it, the student body offered one answer for them. In Mexico some leftist groups joined Moscow's call to battle. Second, independent, anarchist Mexican communists rejected such subservience and pushed a communism that should remain autonomous. Third, students at the Autonomous University of the West voted through their choice of enrollment, endorsing a pro-papal Catholicism that opposed fascism but also any leftist political outlook, regardless of its finer distinctions. Fourth, we have to remind the reader of events triggered by Spanish General Francisco Franco in 1936.

France launched a right wing military revolt that disintegrated into the Spanish Civil War, backed by Catholics beginning in 1936. To make matters worse Adolf Hitler and Benito Mussolini supported the Spanish rebels. Stalin and his Communist Party supported the leftist Spanish government with advisers and weapons. This civil war in Spain placed fear in the hearts of Mexicans who believed fascism would spread to their country as well as other regions of Latin America, just the same way the Haitian Revolution had put fear into the hearts of Latin American elites in the late 1790 s. $^{230}$

Contemporaries in Mexico City and Guadalajara took these global developments as an announcement of what possibly might repeat itself in Mexico if revolutionary politics further intensified. Mexican President Lázaro Cárdenas

${ }^{230}$ Friedrich Schuler, Mexico Between Hitler and Roosevelt: Mexican Foreign Relations in the Age of Lázaro Cárdenas, 1934- 1940, (Albuquerque, University of New Mexico Press: 1998), 57. 
was among those who feared this fascist wave. ${ }^{231}$ The founding of the Autonomous University of the West had not occurred in a global ideological vacuum. In sum a mix of factions and agendas also presented itself in Jalisco's higher education section.

In Guadalajara the student body was split internally between the left leaning students. How they should react to internationalism suggested by popular front politics? Claiming to unite various student groups they interjected themselves between Mexico City educational politicians and urban folk Catholics.

The University of Guadalajara aimed to represent the revolutionary state led educational reform that had been started in 1910. Governor Everardo Topete claimed that, the University of Guadalajara must "have recognized secular ideology and be not a member of any religious association." ${ }^{232}$ Teaching continued despite the intellectual battle that was taking place.

The report also described how, "The organization which he represents must be recognized as of socialistic ideology."233 The university situation was the stage where the divide between secular and Catholic education was played out.

Jalisco's University situation was important because it represented a major difference to Durango. This meant academic freedom from Mexico City's revolutionary curriculum not just dedicated to job skills but also to the creation of a new revolutionary Mexican citizen.

231 Ibid.
232 Ibid.
233 Ibid. 
In this urban center pro - revolutionary forces were split into two camps:

pro - revolutionary faction and internationalist/socialist faction. The internationalist/socialist faction was influenced by the global discussion within communist internationalist circles asking how to react to the rise of fascism. For them, true to Marx's word about religion the Catholic Church in Mexico was just another face of attacking global right wing forces.

And yet Mexico City's revolutionary government did not want to join the anti -Catholic work because Mexican Revolutionaries rivaled the Leninist one and the revolutionary vision of the Anarchists.

Folk Catholics and priests, in this urban setting, suddenly saw themselves confronted by four foes: government educators, government soldiers, autonomous anarchistic communists, and the pro-Moscow Mexican faction. Jalisco's culture of violence here became more complicated because the number of solutions offered doubled.

It is appropriate to stop here a second and point at the difference of worldview of urban folk Catholics and rural folk Catholics. Urban folk Catholics wanted to hold on to the symbols that were dear to them, not too different from those the rural folk prayed to. And in addition urban folk Catholics wanted to modernize and learn a modernist curriculum as long as it afforded them better job skills. However they rejected Mexico City's modernist curriculum because they considered it to be ideological and revolutionary. For them it was too full of aspects totally unrelated to job skills and technical education. 
A first outcome was a collapse of content offered to students. Even though the catalogue promised the continuation of education, sources reported that offerings in the catalogue could no longer be delivered in classrooms. Regardless where one stood ideologically, the quality of education in the University of Guadalajara declined.

This, however, was interpreted along ideological lines. Urban folk Catholics saw this as a vindication of their fears that revolutionary higher education failed their children on an increasing number of levels.

Mexican, pro - revolutionary secular factions received this news only as an attack on the honor of their institution. The resulting clamor, agitation, and accusations only intensified.

Internationalist student factions tried to jump into the raging debates and hoped to pull both sides toward a third perspective that previously had not played a role: Independent Socialist and communist students who rejected Catholic education but also rejected dominance by Mexican revolutionaries. Now it was a competition between two rivaling leftist revolutions and the Catholic Church.

Rivaling higher education worldviews reached its peak of confusion with the founding of a fourth student led group. It called itself Frente Unico. Its radical members wanted to go back to the past and unite the previously described three rivaling educational groups. ${ }^{234}$

${ }^{234}$ Ibid. 
This fourth approach also did not succeed at creating a new consensus. Many students refused to have anything to do with each other and just focused on their studies. $^{235}$

In the end the higher education sphere became completely controlled by Mexican political leaders who thought higher education should be modernist, secular education.

Governor Lorencio Topete followed his brother Governor Everardo Topete's path and kept higher education in Jalisco on the pro-revolutionary secular path.

On the student level groups remained divided. Students who despised Topete nurtured resistance groups. One prominent one was the Federation of University Students in Jalisco. ${ }^{236}$ Others focused their hatred against the new pro Catholic University. One observer tells that, "there was considerable opposition on the part of radical students of the 'Higher Socialistic Education Institutions' to the Autonomous University of Guadalajara....,237

In the end it is appropriate to ask if Jalisco's university situation completely differed from situations involving primary and secondary education? Most importantly the university situation lacked violence against educators. On the university level it was more a battle in the intellectual sense and limited to the urban realm of the capital. Not to be forgotten in urban Jalisco no buildings were

\footnotetext{
${ }^{235}$ Ibid.

${ }^{236}$ NAUS, DOS, 59, M1370, Internal Affairs of Mexico 1930-1939, 13,812.00/JALISCO/150.

${ }^{237}$ NAUS, DOS, 59, M1370, Internal Affairs of Mexico 1930-1939, 13,812.00/JALISCO/184,

Political Report, George H. Winters, October 1936.
} 
burned and teachers were fired but not killed or even physically attacked like in the rural areas. 


\section{Conclusion}

This thesis investigated the Mexican states of Jalisco and Durango as far as the interrelationship between education, religion, politics and violence was concerned. I located new sources in Washington D.C. and London, hoping that they would allow new insights into the history of these two regions during the 1930s.

The investigation suggested reconsidering several assertions previous researchers had made. First, there existed a clear distinct historical period with events that had not existed in the 1920s. It was driven by forced introduction of primary and secondary education and the backlash by the parents of school children in both states. A unique culture of violence was the result that displayed clear behavioral patterns on the part of revolting peasants and federal troops having to deal with the violence. Whereas scientific literature argued there existed only one pro-religious war, called the Cristero rebellion, my research suggested there were two. Charismatic regional leaders fought the first phase of the war against the restrictions set on the folk Catholic community. The first one had focused on the rising revolutionary elite. There existed a second phase focused on education, teachers, and secular school in Jalisco and Durango.

As rebel groups increased and decreased in size it is important to realize that conflict did not represent one large war. Instead, it was a long, drawn out era, which was characterized by an ebb and flow of clashes between government and opposition forces. After inquiring about the composition and structure of 
fighting groups it merits to pay attention to where opposing sides clashed: there was an interrelationship between geography and rebel activity.

My research focused on urban and rural mix of western Mexico. These areas had not been researched in depth. The findings validate that we need that differentiation between rural regions. It would be a mistake to investigate this story simply as a superficial urban, rural category. There were important variations between rural geographical areas in Mexico. Rural is not just rural in Mexico.

In the second phase violence was directed against secular schoolteachers and the buildings where they practiced their jobs. In the second phase also priests emerged as major fighters and equal participants in the backlash against the government.

There emerged a clear geographically defined area where fighting took place. The primary area of violent attacks on secular schoolteachers focused on Southern Durango and Northern Jalisco. Both areas are similar geographically in that they are mountain deserts. Durango's setting was exclusively rural whereas Jalisco had a rural and a complex urban setting.

In other Mexican states changes due to educational reform were received differently. But in the highly folk, rural, and Catholic states of Durango and Jalisco, they were met with extreme backlash and a revival of the old Cristero religious war. 
Previously writers have described priests as emotional supporters in favor of rebellion. My work shows that they were embedded in the fighting forces. In particular Meyer completely ignored this category of participants and saw only young charismatic men without differentiation between two such very different social groups. Any argument that priests represented a higher social group that was merely cheerleading would be mistaken. This rebellion went across all social hierarchies. The educational reform struggle forged a cross social group alliance in the region against Mexico City's state reformers.

A newly discovered feature of this second phase was the creation of large numbers of clandestine schools in both states. As this form of passive resistance was discovered by the federal troops the schools were closed. This response by representatives of the solidifying revolutionary state then fueled the already unstable political situation, a "fire" that was still burning in the state of Jalisco. Attacks on priests and churches further reinforced tensions between church and state. Then anti - clerical laws further limited the number of priests and churches allowed in each state.

When it came to the education of the youth of the state, supporters of regional folk life took up arms against national revolutionary prescriptions. Overwhelmingly, secular schoolteachers became the targets of the violence. Over and over again priests were found as equal fighters, not just spiritual leaders as in the first phase of the war in the 1920s. 
My research has shown that there it was worthwhile paying close attention to gender during the violent clashes. Unfortunately existing scholars have not offered any opinion on this matter. Both male and female secular educators were killed, or attacked or arrested. ${ }^{238}$ But in one incident, a male teacher had escaped whereas there was no account of a female teacher ever escaping. Women played a far greater role in the rebellion in Jalisco than in Durango.

And yet there were significant differences between Durango and Jalisco. In Durango the fight was happening exclusively at the primary and secondary education levels. In Jalisco the fight occurred at the primary, secondary, and, further more, at level of university education.

Events in Jalisco's higher education world were slightly different from those in Jalisco's rural scene. In the urban university setting teachers were not physically abused. Also, students themselves took on the battle and fought in streets. Instead of opening clandestine universities, the higher education setting split into open universities that became two legitimate sources of knowledge students could chose from.

In the university favored by the revolutionists from Mexico City, the student body divided further into two sections. One aligned behind the revolutionary promises of Mexico's Revolution, whereas the other group became absorbed in the global anti-fascist struggle monopolized by the Communist International out of Moscow, Soviet Union. Finally, Jalisco's higher education evolution remained

${ }^{238}$ NAUS, DOS, 59, M1370, Internal Affairs of Mexico 1930-1939, 13,812.00/JALISCO/189. 
in direct political communication with the nation's capital. In rural areas communication was limited between peasants, priests, and the federal army.

Rural experiences in Durango and Jalisco also differed slightly. The rural vastness of Durango made the incidences of violence more spread out across the state. However, in Jalisco fighting occurred mostly in the rural northern region of the state. Jalisco's stronger connection to Mexico City and higher education realm made the situation involving education there more complicated than the rebel situation in Durango.

The sources revealed three slight differences in the experiences of rural culture in Durango and Jalisco. More violence against secular teachers was reported in Jalisco than Durango. Priests were more involved in fighting in Jalisco. In Durango priests participated in more of the non - violent ways of fighting such as the opening of clandestine schools and promotion of the rebel cause but left fighting with federal troops to the gangs. In Jalisco priests led gangs into battle with federal troops.

Fighting in Jalisco was different because rebels could supply themselves directly from the illegal arms market in Mexico City. Durango's peasants did not have this luxury. There the dominance of mining culture influenced the choice of weapons. In Durango there was more use of explosives as a way of fighting federal troops.

My findings suggest that it would be worthwhile to take a second look at other neighboring states during the 1930s and ask what had been their state - 
wide reactions to these secular changes in education. For example, the following states would be the next to look at: Michoacán, Colima, Guerrero. Second, another rural urban region with a university should be studied.

Finally, one could study the outlying areas of Mexico City that were urban as well as rural, meaning having a connection to the modern educational realm that was accepted in Mexico City. Here Toluca comes to mind.

Not to be forgotten, it would be worthwhile to look at other countries in Latin America such as Peru and Brazil. Both nations have similar societies with mestizo populations. One can ask was our story from western Mexico not a national story but part of a larger process of modernization seen around the globe? 
References

Bantjes, Adrian. If Jesus Walked On Earth: Cárdenismo, Sonora, and the Mexican Revolution. Wilmington, Delaware: Scholarly Resource Inc., 1998.

Becker, Marjorie. Setting the Virgin on Fire: Lázaro Cárdenas, Michoacán Peasants and the Redemption of the Mexican Revolution. Berkeley: University of California Press,1995.

Booth, George C. "Socialist Secondary Education in Mexico." The School Review, Vol. 47 , no.8, (1939): 602-609. Chicago: The University of Chicago Press. www.jstor.org/stable/1081784.

Fallow, Ben. Cardenas Compromised: The Failure of Reform in Post Revolutionary Yucatan. Durham: Duke University Press, 2001.

Harris, Charles and Louis R. Sadler. The Secret War in El Paso: Mexican Revolutionary Intrigue, 1906-1920. Albuquerque: University of New Mexico Press, 2009.

Hilton, Stanley E. "The Church - State Dispute Over Education in Mexico From Carranza to Cardenas." The Americas, Vol. 21 no. 2, (1964): 163-183. Academy of American Franciscan History. www.jstor.org/stable/979059.

Kent, Rollin. "Higher Education in Mexico: From Unregulated Expansion to Evaluation." Higher Education, Vol.25 no.1, (1993): 73-83. www.jstor.org/stable/3447732.

Lewis, Stephen E. The Ambivalent Revolution: Forging State and Nation in Chiapas, 1910-1945. Albuquerque: University of New Mexico Press, 2005.

Meyer, Jean A. The Cristero Rebellion: The Mexican People Between Church and State, 1926-1929. Cambridge: Cambridge University Press, 1976.

Reinke, Leanne. "Globalisation and Local Indigenous Education in Mexico." International Review of Education, vol.50, no. 5/6. (2004):483-496. www.jstor.org/stable/4151614.

Sanchez, George I. "Education in Mexico." The Phi Delta Kappan. Vol. 24, no. 3. (1941): 123. Phi Delta Kappa International.www.jstor.org/stable/20331012. 
Schuler, Friedrich. Mexico Between Hitler and Roosevelt: Mexican Foreign Relations in The Age of Lázaro Cárdenas, 1934- 1940. Albuquerque: University of New Mexico Press, 1998.

Sierra, Justo. The Political Evolution of the Mexican People. University of Texas Press: 2014.

Stout, Jospeph A. Jr. Spies, Politics, and Power: El Departamento Confidencial en Mexico, 1922-1946. Fort Worth: TCU Press, 2012.

Vaughan, Mary Kay and Stephen E. Lewis. The Eagle and The Virgin: Nation and Cultural Revolution in Mexico, 1920-1940. Durham: Duke University Press, 2006.

Vaughan, Mary Kay. Cultural Politics in Revolution: Teachers, Peasants, and Schools In Mexico, 1930-1940. Tucson: University of Arizona Press, 1997.

Vaughan, Mary Kay. The State, Education, and Social Class in Mexico: 18801928.Dekalb: Northern Illinois University Press, 1982.

Vaughan, Mary Kay. "Women, Class, and Education in Mexico, 1880- 1928." Latin American Perspectives 4 No. $1 / 2$ Women and Class Struggle (Winter - Spring)(1977): 135-152. Accessed March3,2015,www.jstor.org/stable/2633167. 